Araştırma Makalesi / Research Article

\title{
Mikrobölgeleme Çalışmasına Altlık Oluşturmak Üzere Van Yüzüncü Yıl Üniversitesi Kampüs Zemininin Dinamik Özelliklerinin Belirlenmesi
}

\author{
Determination of Dynamic Soil Properties of Van Yuzuncu Yil University Campus for the Preparation of \\ Microzonation Map
}

\author{
Müge K. AKIN ${ }^{1}$, Mutluhan AKIN², İsmail AKKAYA ${ }^{3}$, Ali ÖZVAN ${ }^{4}$, Serkan ÜNER ${ }^{4}$, Levent \\ SELÇUK ${ }^{4}$, Mücip TAPAN ${ }^{1}$ \\ ${ }^{1}$ Yüzüncü Yıl Üniversitesi, Mühendislik-Mimarlık Fakültesi, Inşaat Mühendisliği Bölümü, VAN \\ ${ }^{2}$ Yüzüncü Yıl Üniversitesi, Mühendislik-Mimarlık Fakültesi, Maden Mühendisliği Bölümü, VAN \\ ${ }^{3}$ Yüzüncü Yıl Üniversitesi, Mühendislik-Mimarlık Fakültesi, Jeofizik Mühendisliği Bölümü, VAN \\ ${ }^{4}$ Yüzüncü Yıl Üniversitesi, Mühendislik-Mimarlık Fakültesi, Jeoloji Mühendisliği Bölümü, VAN
}

$\begin{array}{lll}\text { Geliş (received) } & : & \text { 02 Şubat (February) } 2015 \\ \text { Düzeltme (revised) } & : & \text { 30 Mart (March) } 2015 \\ \text { Kabul (accepted) } & : & \text { 07 Nisan (April) 2015 }\end{array}$

ÖZ

Depremlerde can ve mal kaybına neden olan en önemli etkenlerden biri, yapıların üzerine kurulu olduğu zeminlerin özellikleridir. Zeminlere ait mühendislik özelliklerin belirlenmesi, dinamik yükler altındaki zeminlerin davranışlarının tanımlanmasında ve/veya meydana gelebilecek zararların en aza indirilmesinde büyük önem taşımaktadır. Özellikle 1999 ve sonrası ülkemizde yaşanan depremlerle meydana gelen can ve mal kayıpları, depremin ve yarattığı etkilerin sosyal ve ekonomik boyutunun önemini bir kez daha ortaya koymuştur. Dinamik zemin özellikleri, deprem gibi doğal afetlerin de etkisi dikkate alınarak, mikrobölgeleme esasları doğrultusunda incelenmelidir. Bu amaçla Van Yüzüncü Yıl Üniversitesi (YYÜ) kampüs alanında sondaj çalışmalarından elde edilen bulgular ve jeofizik yöntemler ile dinamik zemin özellikleri ortaya konulmuştur. Zemin koşullarının ortaya konulması amacıyla yapılan arazi çalışmaları kapsamında kampüs alanına yönelik sıvılaşma, zemin büyütmesi gibi unsurlar incelenmiş ve sonuç olarak kampüs alanı için ilerideki planlamalara yol gösterici olması amacı ile bir yerleşime uygunluk değerlendirilmesi yapılmıştır.

Anahtar Kelimeler: CBS, Deprem, Mikrobölgeleme, Sıvılaşma, Van, Zemin büyütmesi. 
Akın, Akın, Akkaya, Özvan, Üner, Selçuk, Tapan

\begin{abstract}
One of the most important factors causing loss of life and property during earthquakes is the soil conditions that the structure is built on. Determination of the soil engineering properties for understanding the behavior of ground under dynamic loads and/or minimizing the losses that may occur is quite crucial. The earthquakes occured in our country especially in 1999 and later on, and the resulting loss of life and property once more emphasized the importance of the social and economic dimensions of the impact created by the earthquake. Dynamic soil properties must be studied in accordance with the principles of microzonation considering the natural disasters such as earthquake. For this aim, the dynamic soil properties of Van Yuzuncu Yil University campus area are determined. Liquefaction, soil amplification and the like for the campus area are investigated through field studies conducted in order to reveal the ground conditions, and consequently the suitability for settlement is evaluated to guide the future planning of the campus.
\end{abstract}

Key Words: GIS, Earthquake, Microzonation, Liquefaction, Van, Soil amplification.

\section{GİRIŞ}

Kolay ulaşımdan ve ekonomik nedenlerden dolayı alüvyon zeminler, yerleşim alanı olarak ülkemizde ve dünyada s1klıkla tercih edilmektedir. Bununla beraber, doğal afetler açısından bakıldığında, Türkiye gibi bir aktif tektonik kuşakta yer alan ülkelerde, depremlerden en fazla etkilenen alanların güncel sedimanter zeminler üzerindeki yerleşim alanları olduğu görülmektedir. Bunun en tipik örnekleri olarak, binlerce insanın hayatını kaybettiği 1939 Erzincan $\left(\mathrm{M}_{\mathrm{w}}=7.9\right), 1942$ Niksar-Erbaa $\left(\mathrm{M}_{\mathrm{w}}=\right.$ 7.0), 1976 Çaldıran $\left(\mathrm{M}_{\mathrm{w}}=7.2\right), 1999$ Adapazarı $\left(\mathrm{M}_{\mathrm{w}}=7.4\right)$ ve Düzce $\left(\mathrm{M}_{\mathrm{w}}=7.1\right)$ depremleri gösterilebilir. Bu nedenle, yerleşim planlamasına ve güvenli alanları belirlemeye katkı sağlayacak olan mikrobölgeleme çalışmaları önem arzetmektedir.
Mikrobölgeleme haritaları hazırlanırken, doğal afetlerin etkileri dikkate alınarak değerlendirme yapılması esas olup, mikrobölgeleme çalıșmaları disiplinler arası katkılar1 gerektirmektedir. Bunun ötesinde, jeolojik, hidrojeolojik, jeoteknik ve jeofizik araştırmalar kullanılarak zeminlerin deprem hareketine bağlı davranışlarının bilinmesi gerekmektedir. Ayrıca, jeolojik ve jeoteknik veriler kullanılarak doğal afetlerin belirlenmesi, kontrol edilmesi ve/veya önlenmesi de mikrobölgeleme çalışmalarında önem arzetmektedir (Bell vd., 1987; Legget, 1987; Hake, 1987; Rau, 1994; Dai vd., 1994, 2001; GDDA (General Directorate of Disaster Affairs), 1996, 2000; Van Rooy ve Stiff, 2001; Ansal vd., 2001; 2004; Topal vd., 2003; Akın, 2009; Akın vd., 2013). 
23 Ekim 2011 Van-Tabanlı depremi $\left(\mathrm{M}_{\mathrm{w}}\right.$ =7.2) sonrasında, depremden en çok etkilenen Van-Merkez ve Erciş ilçesinde olduğu gibi, Yüzüncü Y1l Üniversitesi kampüs alanında da hasar gören yapılarda güçlendirme ve yenileme çalışmaları başlamıştır. Kampüs alanının yeniden düzenlenmesi ve yapılacak yeni binaların yerlerinin belirlenmesi açısından, kampüs alanının zemin özelliklerinin ortaya konulması önem taşımaktadır. Bu çalışmada Yüzüncü Y1l Üniversitesi kampüs alanının zemin özelliklerinin mikrobölgeleme esasları doğrultusunda dinamik özellikleri de ortaya konularak Coğrafi Bilgi Sistemi (CBS) yardımıyla bir yerleşime uygunluk haritasının ortaya çıkarılması amaçlanmıştır. Yüzüncü Yıl Üniversitesi yerleşkesi son 10 yıl içerisinde hızla gelişmekte olduğundan, artan fakülte ve öğrenci sayısına bağlı olarak yeni binaların ve faaliyet alanlarının oluşturulması gerekmektedir. Kampüs alanı, yapımı tamamlanan Tip Fakültesi Hastanesi ve derslikleri, İlahiyat Fakültesi, Merkezi Laboratuvar, Diş Hekimliği Fakültesi, İktisadi ve İdari Bilimler Fakültesi ve yapılmakta olan Mühendislik-Mimarlık Fakültesi ve diğer sosyal/araştırma binaları ile gelişimini sürdürmeye devam etmektedir. Tüm bunlara paralel olarak, artan kullanım alanlarının sayıs1, beraberinde altyap1, enerji ve ulaşım ihtiyaçlarını da doğurmaktadır. Bu çalışma ile Yüzüncü Yı1 Üniversitesi kampüsü ve yakın çevresindeki zeminlerin mühendislik özelliklerinin belirlenmesi ve yerleşime uygunluk haritalarının ortaya konulması sonucunda geleceğe yönelik yerleşim planları için mevcut altlığın daha uygun bir şekilde hazırlanması amaçlanmış olup, bu konuda gerekli çalışmalar yapılmıştır.

Yüzüncü Y1l Üniversitesi kampüs alan1 ve çevresindeki zemin koşullarının statik ve dinamik etkiler altındaki özelliklerinin belirlenmesi ve mikrobölgeleme esasları doğrultusunda hazırlanmış olan bu çalışmada, detaylı olarak arazi ve laboratuvar çalışmaları gerçekleştirilmiştir. Kampüs alanı için önceden yapılmış çalışmalara ek olarak ilave sondaj kuyuları açılmış ve yerinde deneyler yapılmıştır. Ayrıca, mikrotremör gibi ölçümleri kapsayan jeofizik çalışmalarının da kampüs alanı için yapılması sağlanmıştır. Elde edilen veriler 1şığında kampüs alanına ait statik ve dinamik zemin özellikleri ortaya konulmuştur. Bu zemin özellikleri ve yakın geçmişte meydana gelmiş olan Van-Tabanlı ve Edremit depremleri de dikkate alınarak kampüs alanı için gerekli sıvılaşma vb. analizler de gerçekleştirilmiştir. $\mathrm{Bu}$ çalışma sürecinde, kampüs alanı, 2011 depremleri öncesini ve sonrasını kapsayacak şekilde, ayrıntılı olarak değerlendirilmiştir.

\section{ÇALIŞMA ALANI}

Yüzüncü Y1l Üniversitesi kampüsü, Van Gölü'nün doğusunda, Van il merkezinin kuzeybatısında yer almakta olup, kent merkezine yaklaşık $15 \mathrm{~km}$ uzaklıktadır. Kampüs alanı, batıda Bardakçı köy yolu, doğuda Maden Tetkik Arama Doğu Anadolu Bölge Müdürlüğü ve Erciş - Van karayolu, güneyde ise Van Gölü ile sınırlanmaktadır (Şekil 1). 


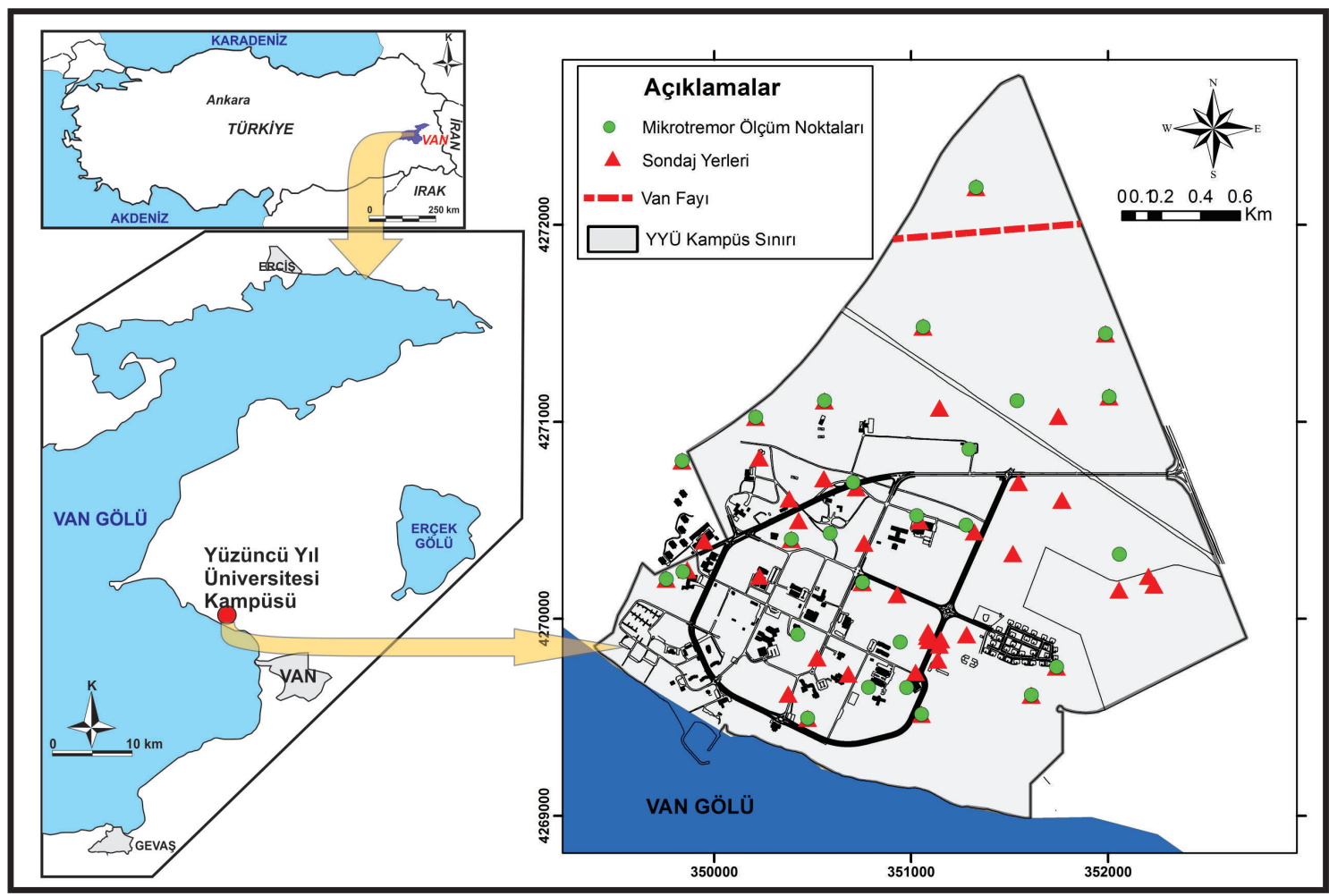

Şekil 1. Yüzüncü Y1l Üniversitesi kampüs alanı yer bulduru haritası.

Figure 1. Location map of Yuzuncu Yil University campus area

\section{ÇALIŞMA ALANININ JEOLOJISİ}

Van Gölü Havzası, Paleozoik yaşıı Bitlis Metamorfikleri, Üst Kretase ofiyolitleri ve Van formasyonu olarak isimlendirilen OligosenMiyosen yaşlı derin denizel çökellerden oluşan bir temel üzerinde bulunmaktadır. Havzada temel kayaçların üzerini, havzanın batısında ve kuzeyinde yer alan Nemrut ve Süphan volkanlarına ait Kuvaterner yaşlı volkanikler ve bunlarla eş yaşı Van Gölü formasyonu olarak isimlendirilen gölsel çökeller uyumsuz olarak örter. Havza çökel dolgusu, travertenler ve pekişmemiş güncel akarsu sedimanlarıyla sona ermektedir (Aksoy, 1988; Acarlar vd., 1991, Örçen vd., 2004).
Van Gölü’ne ait güncel gölsel çökeller yaygın olarak Van Gölü'nün doğusunda, sinırlı olarak da güneyinde ve kuzeyinde yer almaktadır. İnce-orta tabakalı, az pekişmiş çakıl-kum ve kil-silt ardalanmasından oluşan gölsel çökeller, Van Gölü su seviyesindeki büyük ölçekli oynamalar sebebiyle akarsu çökelleri tarafından kesilmiştir. Çalışma alanı, Van Gölü havzası içerisinde Van Gölü'nün doğusunda yer almaktadır. Van Gölü Havzası, Paleozoyik'ten günümüze kadar farklı yaşlardan kayaç türlerinin yüzeylendiği, tektonizmanın da etkisiyle oldukça karmaşık bir stratigrafinin gözlendiği bir alandır. Van Gölü havzasının güneyinde Bitlis Masifi'ne ait metamorfik kayaçlar, batısında ve kuzeyinde genç volkanik 
ve volkanoklastik kayaçlar, doğusunda ise ofiyolitli kayaçlar ile Kuvaterner yaşlı güncel akarsu ve göl sedimanları (kırıntılılar ve karbonatlar) yaygın olarak yüzeylenmektedir.

$\mathrm{Bu}$ çalışmada Acarlar vd. (1991)'e ait stratigrafi ve birim adlamaları esas alınmıştır. Yüzüncü Y1l Üniversitesi kampüs alanı bu çalışmaya göre Kuvaterner (Pleyistosen) yaşlı eski gölsel çökeller üzerinde yer almaktadır. Eski göl çökellerinin toplam kalınlığ 1 yaklaşık 150 metredir (Acarlar vd., 1991). Önceki çalışmalara göre, kampüs alanında eski göl çökellerinin yanında eski akarsu çökelleri ile güncel akarsu çökellerine de rastlanılmıştır (Şekil 2) (Acarlar vd., 1991; Selçuk, 2003; Koçyiğit, 2013).

\section{Eski Göl Çökelleri (Qeg)}

Eski göl çökelleri, beyaz, kirli beyaz, gri, karbonatlı, killi ve kumlu düzeylerden oluşur. İnceleme alanındaki eski göl çökelleri, Geç Pleyistosen yaşlı kabul edilmiştir.

\section{Eski Göl-Akarsu Çökelleri (Qega)}

Genellikle kırıntılılardan oluşan birim, ayrılmamış eski göl ve akarsu çökellerinden oluşur. Bunlar eski göl tabanı, eski kıyı çökelleri ile bunlarla ara katkılı akarsu çökellerini kapsar. Birim Geç Pleyistosen yaşlı kabul edilmiştir.

\section{Alüvyon (Qal)}

Özellikle kampüs alanının doğusundaki akarsu yataklarında ve çöküntü alanlarında depolanan tutturulmamış çakı1, kum, silt ve kilden oluşur (Acarlar vd., 1991).

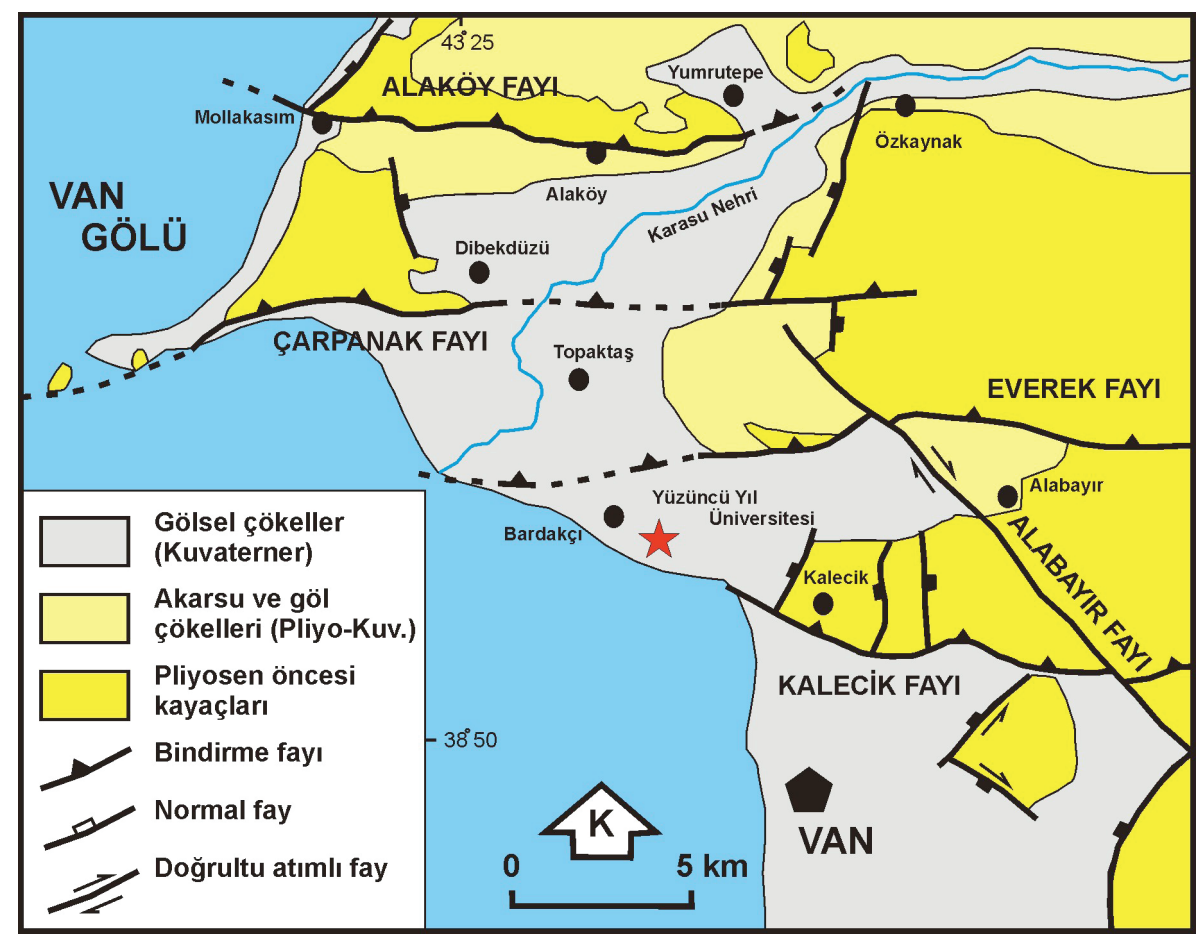

Şekil 2. Kampüs alanı ve çevresinin genel jeoloji haritası (Koçyiğit, 2013'ten alınmıştır).

Figure 2. Geological map of the campus area and its vicinity (taken from Koçyiğit, 2013) 


\section{TEKTONIZMA VE DEPREMSELLIK}

\section{Çalıșma alanı ve yakın çevresindeki önemli}

faylar

Van Gölü havzasında yeni tektonik dönem, Pliyo-Kuvaterner yaşlıdır (Koçyiğit vd., 2001). $\mathrm{Bu}$ dönem K-G doğrultulu sıkışma rejimi ürünü, D-B doğrultulu ters faylar, KB-GD doğrultulu sağ yönlü ve KD-GB doğrultulu sol yönlü doğrultu atımlı faylar ile K-G doğrultulu genişleme yapıları tarafından temsil edilir (Şaroğlu ve Y1lmaz, 1986; Bozkurt, 2001; Koçyiğit vd., 2001; Koçyiğit, 2013). Bunların en bilinenleri; ters fay karakterli Ağartı, Alaköy, Everek ve Gürpınar fayları ile doğrultu atımlı fay karakterindeki Çaldıran, Erciş, Alabayır ve Çakırbey faylarıdır (Koçyiğit vd., 2001; Özkaymak, 2003; Özkaymak vd., 2012; Koçyiğit, 2013) (Şekil 3).

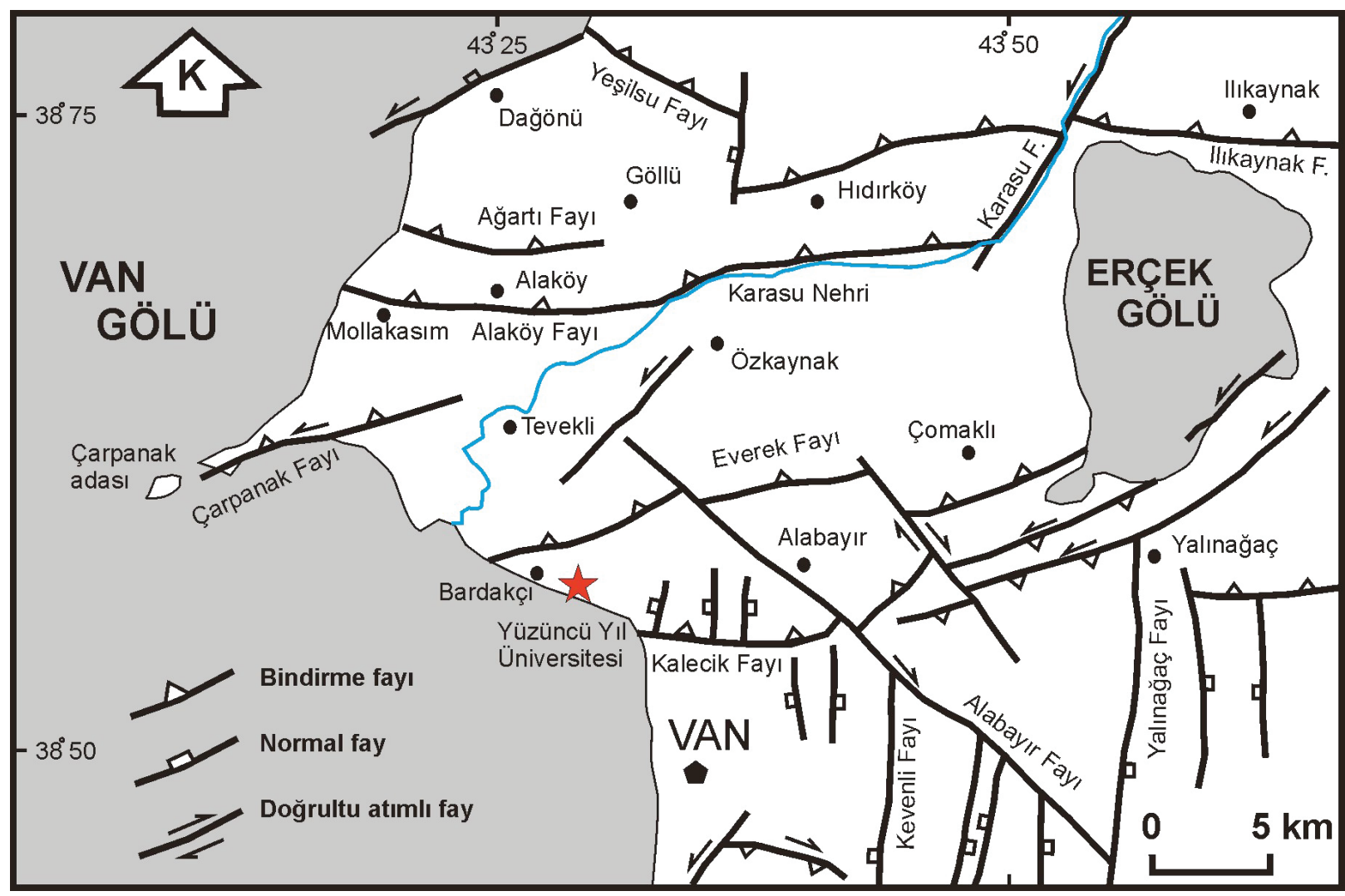

Şekil 3. Van Gölü ve yakın çevresinin sismotektonik haritası (Koçyiğit, 2013’ten alınmıştır).

Figure 3. Seismotectonic map of Lake Van and its surroundings (taken from Koçyiğit, 2013) 


\section{Kampüs Alanı ve Yakın Çevresinin Depremselliği}

Yapılan çalışmalar ve gözlemler, depremlere bağlı hasarlarda, yapıların özellikleri, deprem kaynak özellikleri ve bölgesel jeoteknik koşulların son derece önemli olduğunu ortaya koymaktadır. Deprem dalgaları, zemin tabakaları içinden geçerken, depremin özelliklerinin değişmesi ile birlikte, zemin tabakalarının özelliklerini de (sıvılaşma, dayanım azalması, zemin büyütmesi, vb.) etkilemektedir. Bu açıdan değerlendirildiğinde zemin koşullarının dinamik yükler altındaki davranışlarının belirlenmesi, deprem hasarlarının büyük ölçüde azaltılmasını sağlayacaktır. Örneğin bölgesel jeolojik, tektonik ve topoğrafik koşullar, deprem dalgalarının özelliklerini önemli ölçüde değiştirerek, aynı sismik hareketlere maruz kalan birbirine yakın bölgelerde, farklı derecelerde hasara yol açabilmektedir (Ansal, 1999). Bunun en büyük sebebi ise yerel ölçekte zemin koşullarının farklılığından veya ortamın heterojenitesinden kaynaklanmaktadır. Bununla birlikte Yüzüncü Y1l Üniversitesi kampüs alanı ve yakın dolayının yer aldığı sismik açıdan aktif olan bölgede, geçmiş dönemlerde yaşanan depremler sonucunda zemin özelliklerine bağlı olarak birçok can ve mal kaybı meydana gelmiştir. Bölgede tarihsel dönemlerde VIII ve IX şiddetinde, aletsel dönemde ise $M=5.0$ - 7.3 büyüklüğünde depremler meydana gelmiştir. Buna ek olarak geçtiğimiz yıllarda meydana gelmiş depremler de kampüs alanı açısından önem arz etmektedir.

23 Ekim ve 9 Kasım 2011 tarihlerinde Van Gölü'nün D-KD'da meydana gelen sirası ile $\mathrm{M}_{\mathrm{w}}$ $=7.2$ ve $\mathrm{M}_{\mathrm{w}}=5.6$ büyüklüğündeki depremler, Yüzüncü Y1l Üniversitesi kampüs alanında da bir kısımyapıların hasargörmesine neden olmuştur. Van ili ve çevresinde meydana gelen bu depremlerde, 600'ün üzerinde vatandaşımız hayatını kaybetmiş, 4000'den fazla kişi yaralanmış, 150.000 kişi evsiz kalmış, 2309 bina yıkılmış, 14000'den fazla bina kullanılamaz hale gelmiş ve yaklaşık 18000 bina ise orta derecede hasar görmüştür (CEDIM, 2011; Selçuk ve Aydın, 2012).

23 Ekim 2011 tarihinde meydana gelen $\mathrm{M}_{\mathrm{w}}=7.2$ büyüklüğündeki depremin merkez üssü, Yüzüncü Y11 Üniversitesi kampüs alanının yaklaşık 25 km kadar kuzeyinde, Tabanlı köyü olarak belirtilmiştir (KOERI, 2011). 23 Ekim 2011 Van depremi ana şok ve artçı depremlerin lokasyonunu gösterir harita Şekil 4'te verilmiştir. Şekilde yer alan sarı elips, depremin kaynağı olan Van fayını göstermektedir. Şekil 5'te ise Van fayına ait gözlenen yüzey kırığı, depremin merkez üssü ve Yüzüncü Yıl Üniversitesi kampüs alanına olan uzaklıkları gösterilmektedir.

23 Ekim 2011 depremi, Erciş ilçesinde birçok yapının yıkılmasına, ağır derecede hasar görmesine ve can kaybına neden olmuştur. Bu deprem, yine merkez üssüne yakın Alaköy, Otluca, Tevekli, Mollakasım, Ayanıs köyleri ile birlikte Yüzüncü Y1l Üniversitesi kampüsünde ve Van il merkezinde can kayılarına ve hasara neden olmuştur. $\mathrm{Bu}$ depremden sonra meydana gelen artçılar ile birlikte, 9 Kasım 2011 tarihinde Edremit merkezli $\mathrm{M}_{\mathrm{w}}=5.6$ büyüklüğündeki Edremit depremi, Van'da ve Yüzüncü Yıl Üniversitesi Kampüs alanında daha şiddetli hissedilmiş, ilk depremde herhangi bir hasara uğramamış yapılar ile birlikte hafif hasarlı binalar, orta ve ağır derecede hasara uğramış ve bazı binalar yıkılmıştır (CEDIM, 2011).

Van il merkezinde ve Yüzüncü Y1l Üniversitesi kampüs alanında çoğunlukla eski göl çökelleri bulunmaktadır. $\mathrm{Bu}$ tür zeminler orta ve büyük ölçekli depremlerde, gerek depremin tekrarlı yüklerinden, gerekse zeminden kaynaklanan deformasyonlardan etkilenebilirler. 


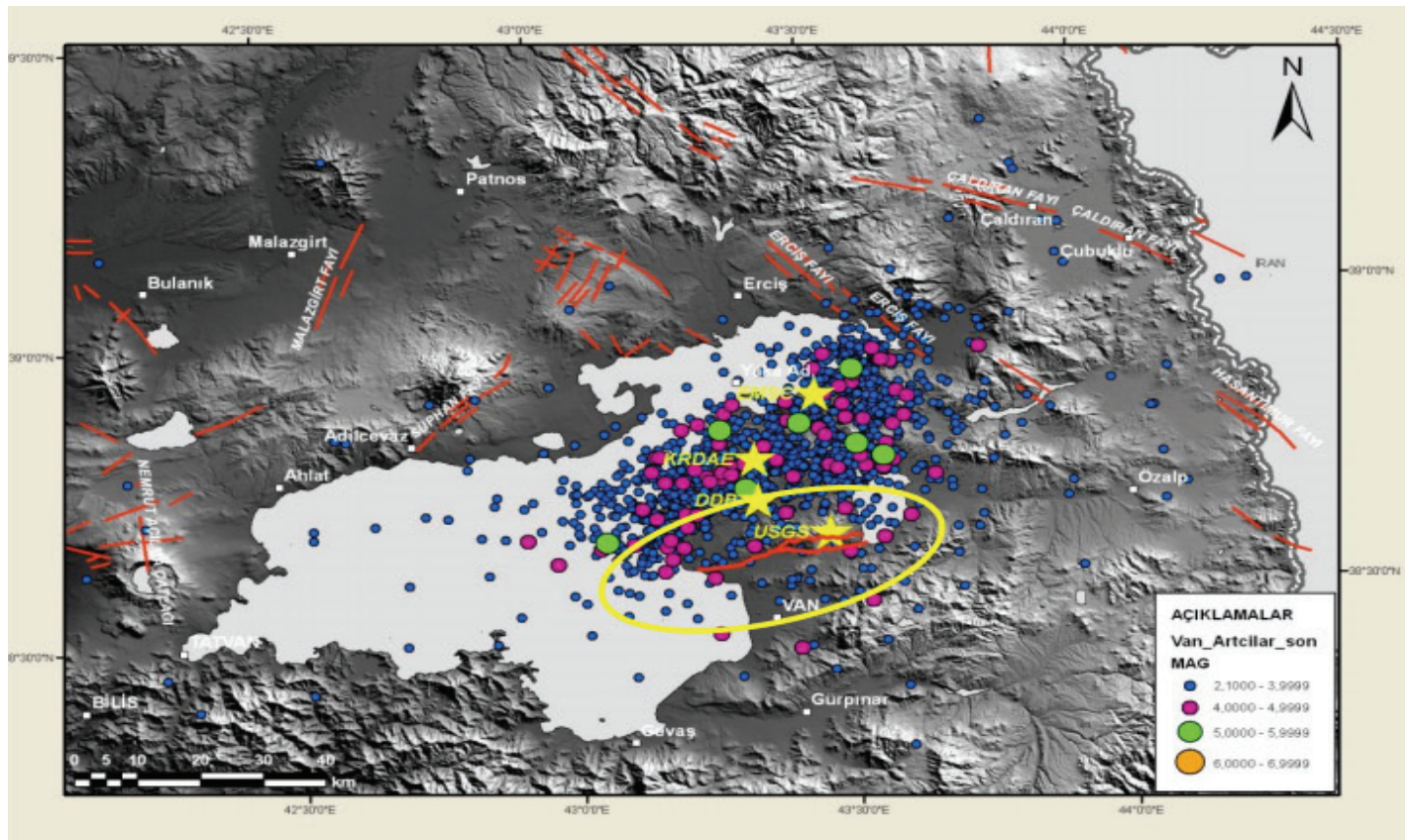

Şekil 4. 23 Ekim 2011 Van depremi ana şok ve artçı depremlerin lokasyonunu gösterir harita (Sarı daire depremin kaynağı olan Van fayını göstermektedir) (Emre vd., 2011).

Figure 4. Location map of the 23 October 2011 Van earthquake mainshocks and aftershocks (Yellow circle shows the Van fault that is the source of earthquake) (Emre et al., 2011).

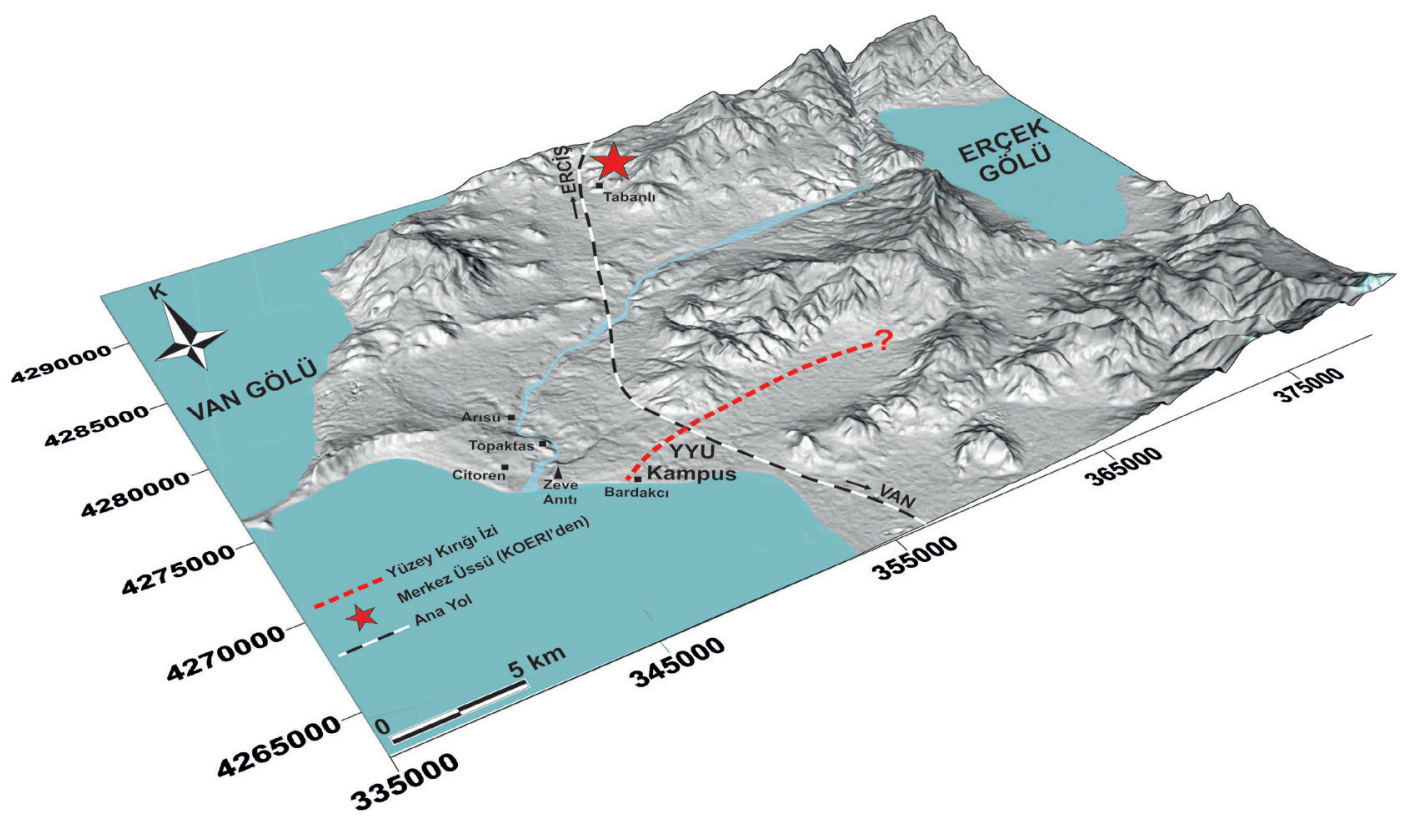

Şekil 5. 23 Ekim 2011 Van depremi kaynağı olan Van fayı ve YYÜ kampüs alanı (Akın vd., 2013’ten değiştirilerek alınmıştır). Figure 5. Van fault which is the source of 23 October 2011 Van earthquake and YYÜ campus area (modified after Akın et al., 2013). 


\section{ARAŞTIRMA YÖNTEMI}

Yüzüncü Y1l Üniversitesi kampüs alanı ve yakın çevresi, Doğu Anadolu Bölgesi'nde yer alan Van Gölü Kapalı Havzası'nda yer almaktadır. Arazi çalışmaları kapsamında, çalışma alanında yüzeylenen Kuvaterner yaşlı birimler ayrıntılı olarak incelenmiştir. Kuvaterner yaşlı birimler çökelme koşullarından dolayı kısa mesafelerde heterojen bir yapı göstermektedir.

\section{Arazi ve Laboratuvar Çalışmaları}

Çalışma kapsamında ilk olarak, mevcut birimlerin jeoteknik özelliklerinin belirlenmesi amacıyla örnek alma işlemleri gerçekleştirilmiştir. Kampüs alanında, 2011
Van depremi ve sonrasında farklı amaçlar için açılan 100'den fazla sondaj kuyusundan uygun olan 45 tanesi analizlerde kullanılmış, bunlara ek olarak, farklı noktalarda toplam 150 metrelik sondaj kuyusu açılmıştır. Bu çalışma kapsamında açılan kuyular (MSK 1-MSK 5) 30 metre derinliğinde olup, her 1 metrede SPT ile örselenmiş ve Shelby tüp ile örselenmemiş örnek alımı gerçekleştirilmiştir (Şekil 6).

Yerleşke içinde yapılan sondaj çalışmalarından elde edilen örnekler üzerinde, zeminlerin fiziksel özelliklerine yönelik laboratuvar deneyleri gerçekleştirilmiş ve zemin sınıflamaları yapılmıştır.

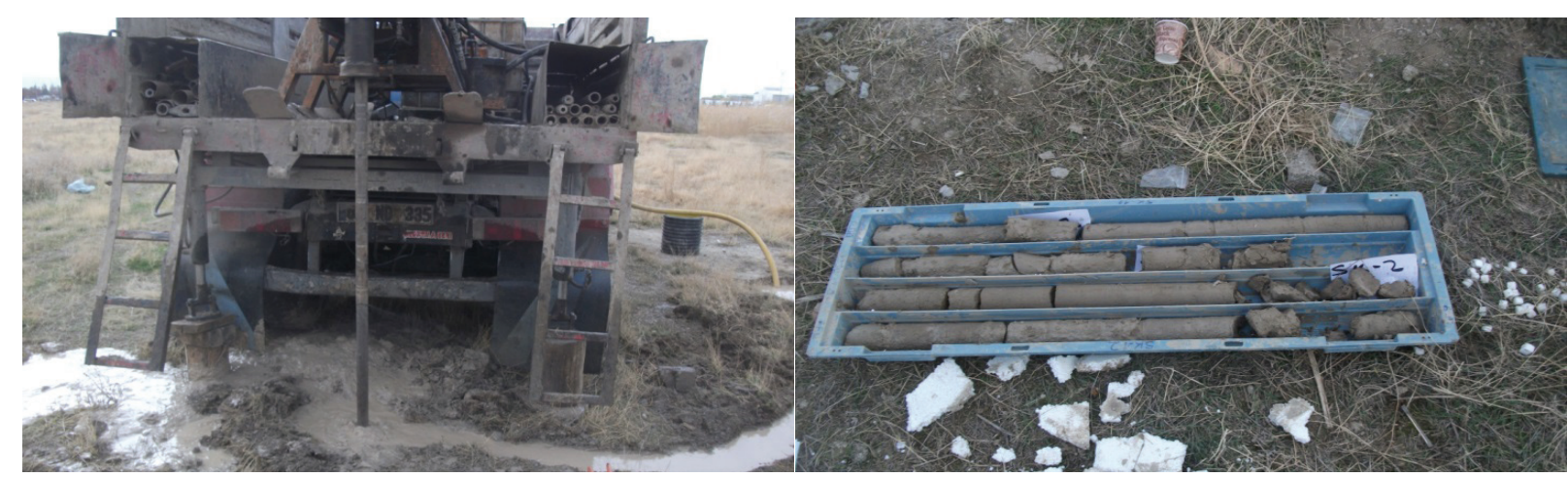

Şekil 6. Sondaj çalışmalarına ait fotoğraflar.

Figure 6. Drilling photos.

\section{Jeofizik Çalışmalar}

Çalışma alanında yüzeylenen Kuvaterner yaşlı gölsel birimlerin; elektrik özdirençleri, sismik dalga hızları ve derinlikleri gibi statik özellikleri ile zemin hâkim periyodu, zemin büyütmesi, kayma modülü, poisson oranı gibi özellikleri, jeofizik yöntemler kullanılarak önceki çalışmalarda belirlenmiştir (Selçuk, 2003). Bu çalışmada, zeminlerin dinamik özelliklerinin belirlenmesi için mikrotremor yöntemi kullanılmıştır. Depremlere bağlı hasarların tespitinde jeolojik birimlerin dinamik özelliklerinin belirlenmesi oldukça önemlidir. Mikrotremor ölçümleri, son yıllarda, dünyada olduğu gibi ülkemizde de yaygın olarak kullanılmayabaşlananpratikbiryöntemdir.Zemin hakim titreşim periyodunu belirlemeye yönelik olan mikrotremor yöntemi, mikro titreşimlerin kaydedilmesi temeline dayanmaktadir. $\mathrm{Bu}$ titreşimlerin genlikleri 0.1 - 1 mikron, periyotları 
ise 0.005 - 2 sn arasında değişmektedir (Kanai ve Tanaka, 1954; 1961). Bu çalışmada, yatay hareket bileşenlerinin düşey hareket bileşenine göre spektral oranlarının belirlendiği Nakamura Yöntemi`ne göre ölçümler alınmıştır (Nakamura, 1989). Ölçümlerde GURALP marka 3 bileşenli CMG-6TD model sismograf kullanılmıştır. Kayıtlar için 20 ile 30 dakikalık ölçüm süresi kullanılarak, $100 \mathrm{~Hz}$ örnekleme aralığında veriler alınmıştır. Her bir gürültü kaydı, 0.1 - 10 $\mathrm{Hz}$ arasında Butterworth Band-geçişli filtre ile filtrelenmiştir. Yatay/düşey spektral oran $(\mathrm{H} / \mathrm{V})$ eğrilerinin hesaplanması için her bir bileşenden elde edilen veri pencerelenmiş, her bir pencereye ait verinin Fourier spektrumları alınmıştır. Yatay/ Düşey spektral oran eğrileri her bir pencere için hesaplanmış, hesaplanan eğrilerin ortalaması alınarak ölçüm noktasını temsil eden spektral oran eğrisi ve standart sapması belirlenmiştir.
Spekturumlar elde edilirken Parzen pencere uygulaması yapılmıştır. Ayrıca 40 saniyelik Konno-Ohmachi penceresi kullanılarak \% 10 cosinüs tapering ile düzgünleştirilmiştir.

Kampüs alanının dinamik zemin özelliklerinin incelenmesi çalışması kapsamında toplam 17 noktada mikrotremör ölçümü alınmıştır. Bu ölçümlere ilişkin örnek bir veri Şekil 7'de verilmiştir. Veri-işlemi tamamlanan mikrotremor kayıtlardan kampüs alanı için üretilen zemin hakim periyodu ve büyütme haritası oluşturulmuş ve analizler kısmında yer verilmiştir. Elde edilen verilerin işlenmesinde SESAME (Site EffectS assessment using AMbient Excitation) adlı proje kapsaminda geliştirilmiş ve literatürde yaygın olarak kullanılan GEOPSY yazılımı kullanılmıştır (Wathelet vd., 2008).

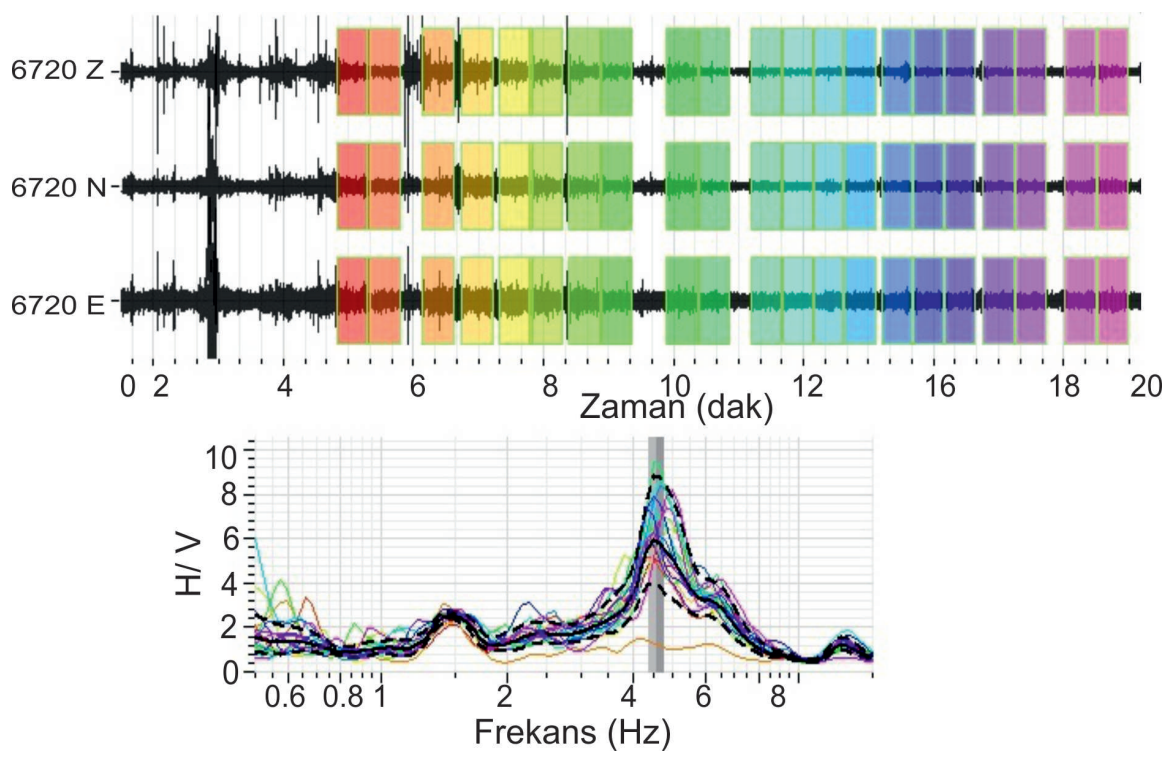

Şekil 7. Kampüs alanında elde edilen bir mikrotremor verisi ve yorumlanmış durumu.

Figure 7. Microtremor data and interpretation for the campus area. 


\section{KAMPÜS ZEMINLERININN FİİKSEL VE MEKANIK ÖZELLÍKLERİ}

Yerleşke içinde yapılan sondaj çalışmalarından elde edilen örnekler üzerinde yapılan deneylerin sonuçlarına bağlı olarak, inceleme alanındaki zeminlerin fiziksel ve mekanik özellikleri bu bölüm altında değerlendirilmiştir. Değerlendirmelerde, daha önceden kampüs içerisinde açılmış olan sondaj kuyularının yanı sıra, özellikle yeni açılan 5 adet sondaj kuyusuna (MSK - 1, 2, 3, 4 ve 5) ait verilerden de faydalanılmıştır.

Laboratuvarda yapılan zemin tanımlamasına yönelik elek analizi sonuçları dikkate alındığında, Yüzüncü Y1l Üniversitesi kampüs alanındaki zeminlerin önemli bir bölümünün ince taneli olduğu dikkati çekmektedir (Şekil 8). Buna göre, kampüs alanındaki en yaygın zemin sınıfi düşük plastisiteli kil (CL)'dir. Bu zemin türünü sırasıyla düşük plastisiteli silt (ML), killi kum (SC), yüksek plastisiteli kil $(\mathrm{CH})$ ve diğerleri izlemektedir.

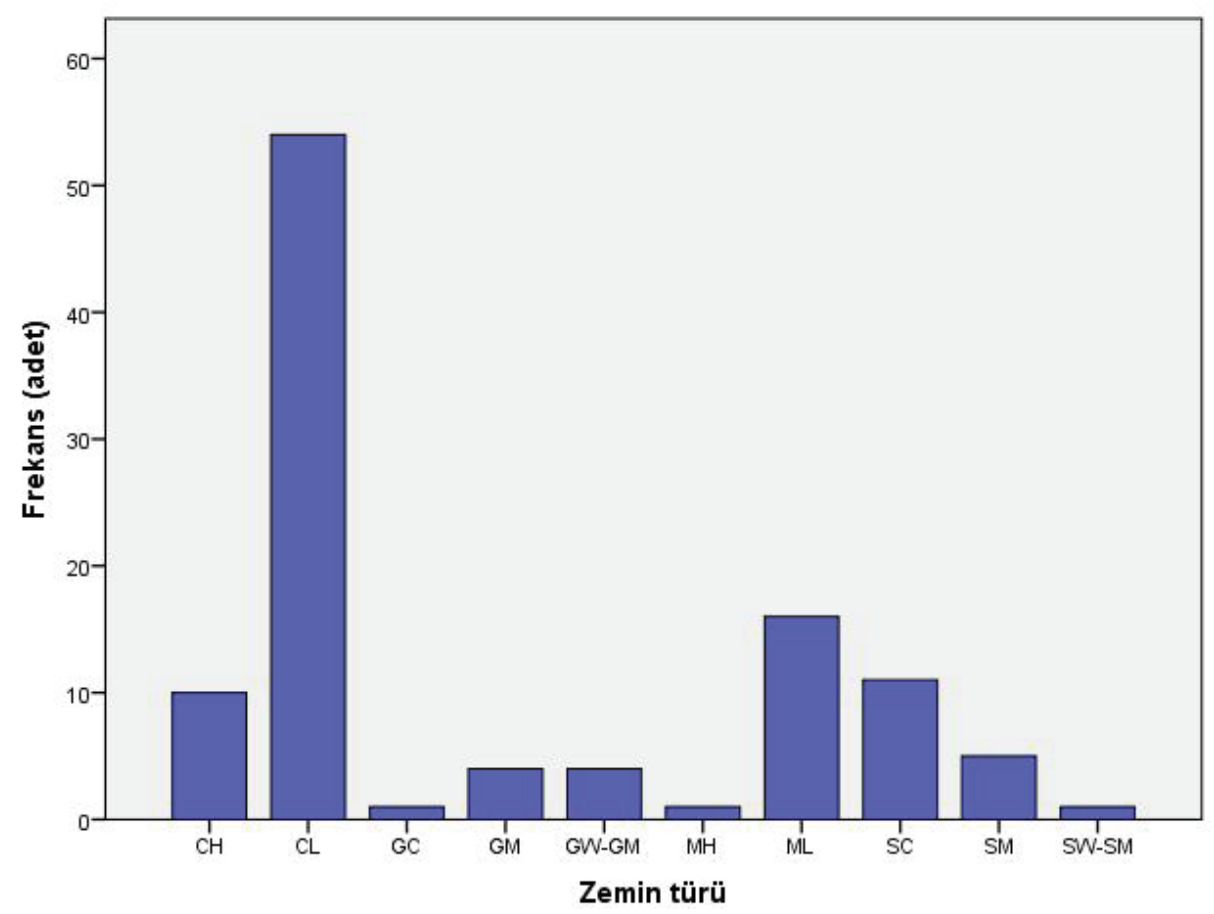

Şekil 8. Yüzüncü Y1l kampüs alanındaki zemin türlerinin frekans dağılımı.

Figure 8. Frequency distribution of the soil types in the Yuzuncu Yil campus area.

İnceleme alandaki ince taneli zeminlerin plastisite abağı üzerindeki dağılımları incelendiğinde, örneklerin büyük oranda likit limitlerinin \% 50’nin altında yani düşük plastisiteli olduğu görülmektedir (Şekil 9). Plastisite indisi değerleri ise genelde \% 30'dan daha düşüktür. 


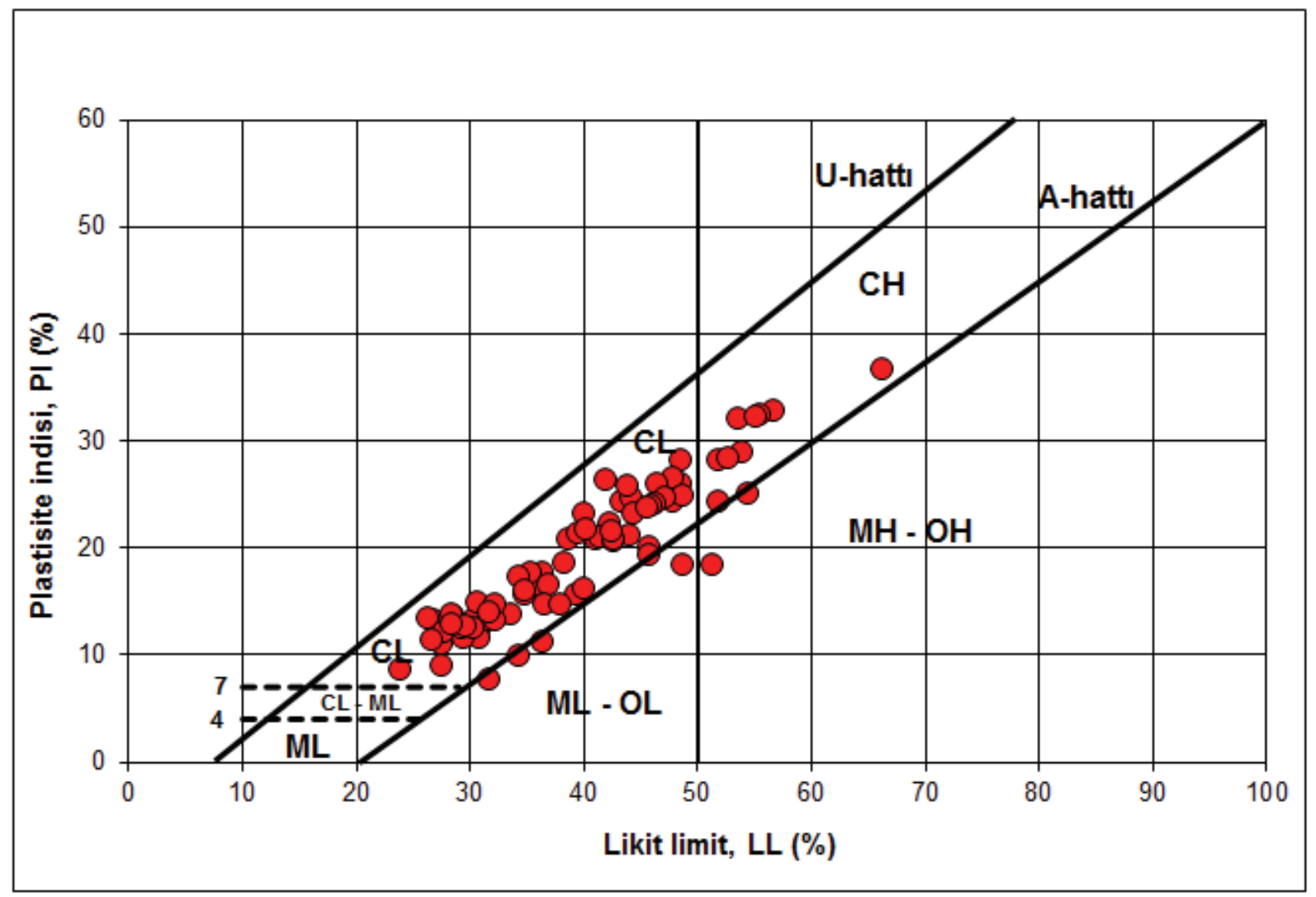

Şekil 9. Yüzüncü Yıl kampüs alanındaki ince taneli zeminlerin plastisite abağı üzerindeki dağılımı.

Figure 9. Distribution of fine grained soils of the Yuzuncu Yil campus area on the plasticity chart.

Kampüs alanındaki sondajlardan alınan örneklerin ince tane oranı değerlerinin (200 nolu eleğin altına geçen) dağılımı Şekil 10'da sunulmaktadır. 106 örneğe ait ince tane oranı dağılımına bakıldığında, çoğunlukla \% 80'in üzerinde olduğu görülmektedir. İri taneli zeminlerdeki en düşük ince tane oranı ise \% 10'lar mertebesindedir. \%10'un altında ince tane oranı bu örnek grubu için tespit edilememiştir. $\mathrm{Bu}$ durum çalışma alanındaki zeminlerin dinamik etkiler altında meydana gelebilecek sıvılaşma potansiyeli üzerinde etkili olmakta ve sahadaki sıvılaşma potansiyelini düşürmektedir. $\mathrm{Bu}$ olguyu destekleyecek şekilde, sonraki bölümlerde değinilen sıvılaşma analizleri incelendiğinde, kampüs sahasındaki sıvılaşma potansiyelinin genel olarak çok düşük-düşük olduğu ve bölgesel olarak sıvılaşma potansiyeli yüksek olan alanların bulunduğu tespit edilmiştir. Sıvılaşma potansiyelinin düşük olmasındaki en önemli etkenler, inceleme alanında yayılım gösteren zeminlerin sıkı-katı/çok katı özellik göstermesinin yanı sıra, ince tane oranlarındaki yüksekliktir. 


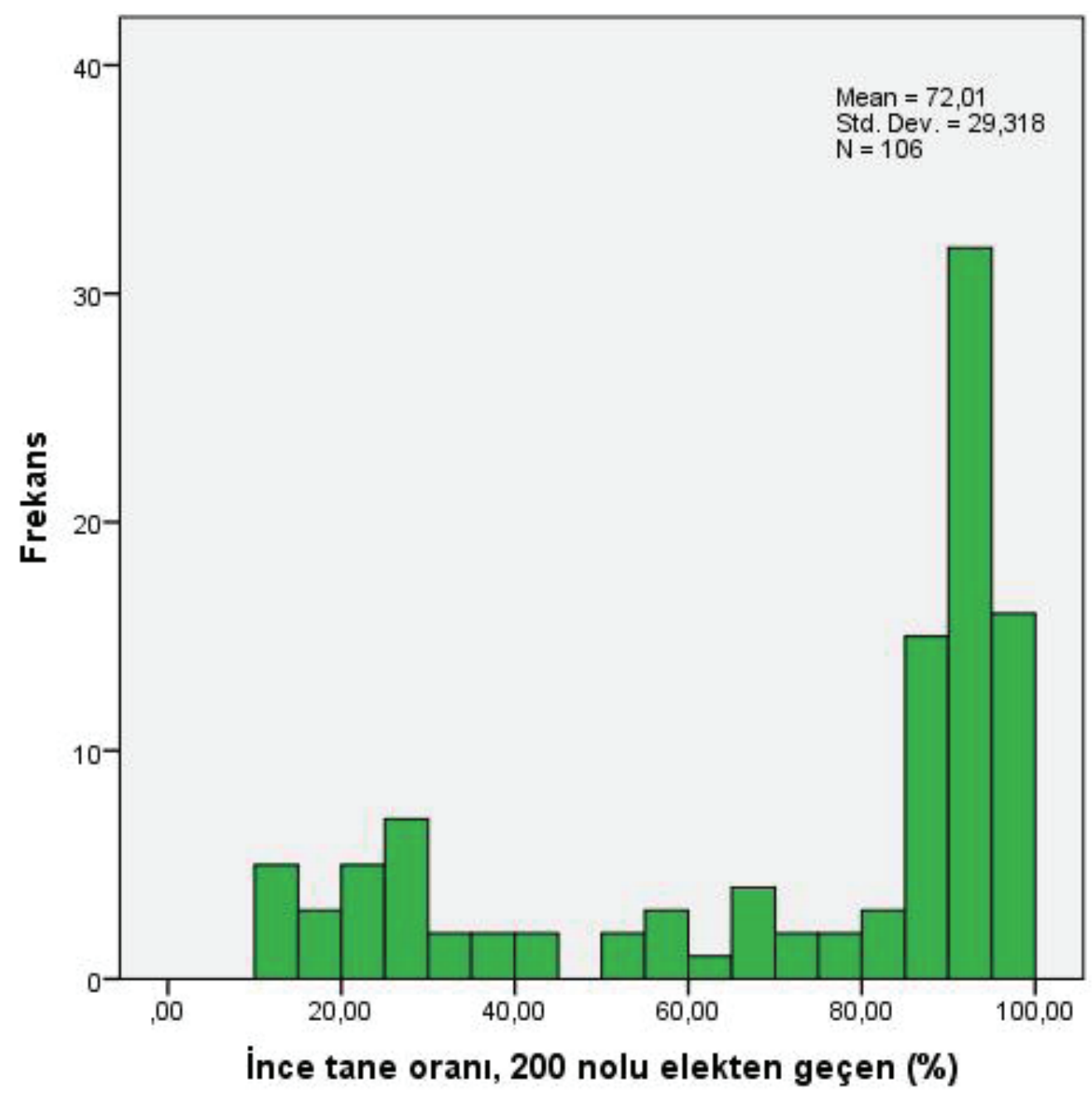

Şekil 10. Yüzüncü Y1l kampüs alanındaki zeminlerin ince tane oranlarının istatistiksel dağılımı.

Figure 10. Statistical distribution of the fine contents of soils in the Yuzuncu Yil campus area.

Kampüs alanındaki zeminlerin doğal su içeriklerine bakıldığında, örneklerin genel olarak suya doygun olmadıkları gözlenmektedir. Şekil 11'de, incelenen örneklerin doğal su içeriklerinin istatistiksel dağılımı verilmiştir. Buna göre, örneklerin doğal su içeriği yoğun olarak $\quad \% \quad 10 \quad-\quad \% \quad 25$ aralığında dağ 11 ım göstermektedir.
Sondaj çalışmaları sırasında alınan örselenmemiş örneklere göre, inceleme alanındaki zeminlerindoğal yoğunluğu $17.6 \mathrm{kN} / \mathrm{m}^{3}$ 'ünüzerinde olup, ortalama olarak 18.4 kN/m³'tür (Şekil 12). Bu değer, ince taneli killi zeminler için geçerlidir. Elde edilen sonuçlar, inceleme alanındaki zeminlerin katı özellikte olduğu gerçeğini desteklemektedir (Selçuk, 2003; Özvan vd., 2005). 


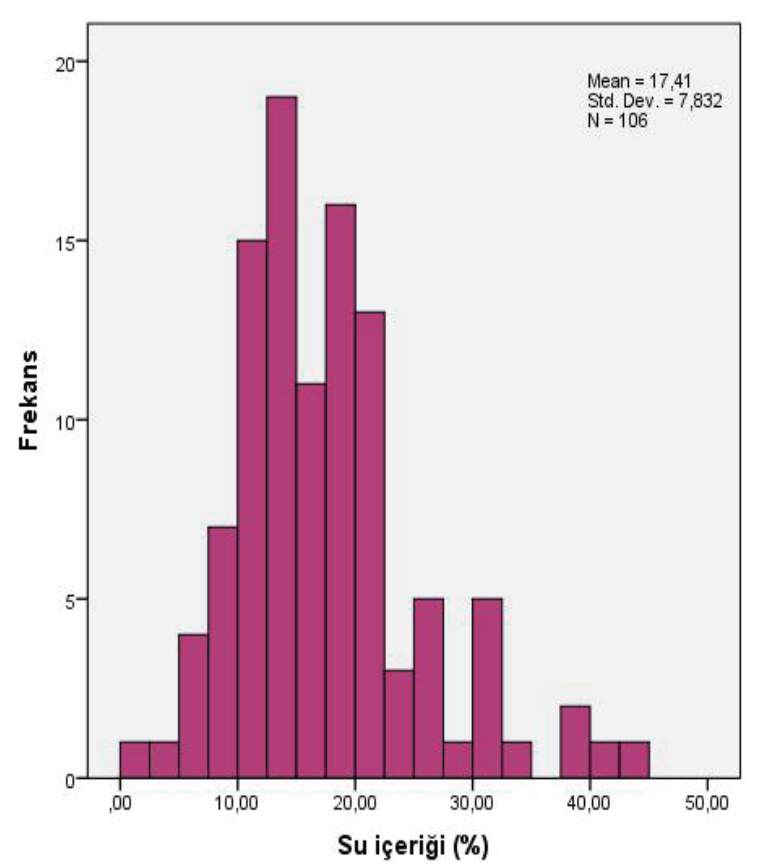

Şekil 11. Yüzüncü Y1l Üniversitesi kampüs alanındaki zeminlerin doğal su içeriklerinin istatistiksel dağılımı.

Figure 11. Statistical distribution of the water content of soils in the Yuzuncu Yil campus area.

İnceleme alanındaki zeminlerin mekanik özellikleri incelediğinde, killi zemin örneklerinin yüksek makaslama dayanımı değerlerine sahip olduğu anlaşılmaktadır. 34 adet örselenmemiş örnek üzerinde yapılan üç eksenli deney (UU) sonuçlarına göre kampüs alanındaki killi zeminlerin kohezyon değerlerinin en düşük 0.31 $\mathrm{kg} / \mathrm{cm}^{2}$, en yüksek $0.90 \mathrm{~kg} / \mathrm{cm}^{2}$ ve ortalama 0.73 $\mathrm{kg} / \mathrm{cm}^{2}$ olduğu tespit edilmiştir. İçsel sürtünme açıs1 değerlerinin ise, en düşük $3^{\circ}$, en yüksek $9^{\circ}$ ve ortalama $5.3^{\circ}$ olduğu tespit edilmiştir. Kampüs alanındaki CL-CH türü zeminlerin makaslama dayanım değerlerinin istatistiksel dağılımı Şekil 13’te gösterilmiştir.

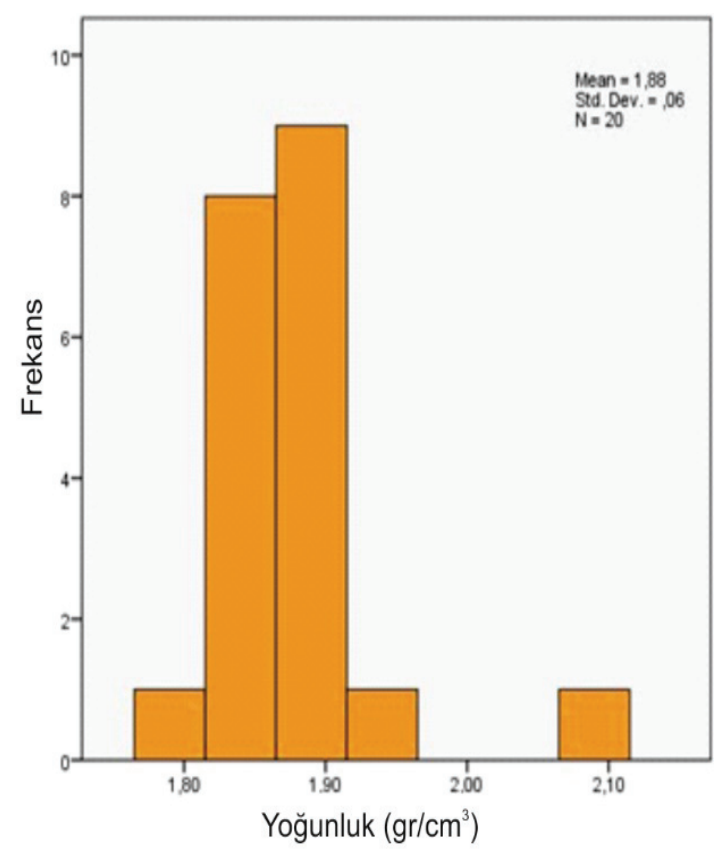

Şekil 12. Yüzüncü Y1l kampüs alanındaki zeminlerin doğal birim hacim ağırlığı değerlerinin istatistiksel dağılımı.

Figure 12. Statistical distribution of the unit weight values of soils in the Yuzuncu Yil campus area.

İnceleme alanındaki killi zeminlerin (CL-CH) şişme ve oturma özellikleri de ayrıca incelenmiştir. Aktivite açısından değerlendirildiğinde, kampüs alanındaki killerin çoğunlukla "orta-yüksek" aktiviteye sahip oldukları görülmektedir (Şekil 14). Şişme potansiyeli açısından ele alındığında ise kampüs genelindeki killi malzemenin şişme potansiyelinin Seed vd. (1962) abağına göre genel olarak "düşük-orta" olduğu belirlenmiştir. Bunun yanı sıra bazı örneklerin şişme potansiyelinin de yüksek olduğu belirlenmiştir (Şekil 14). 

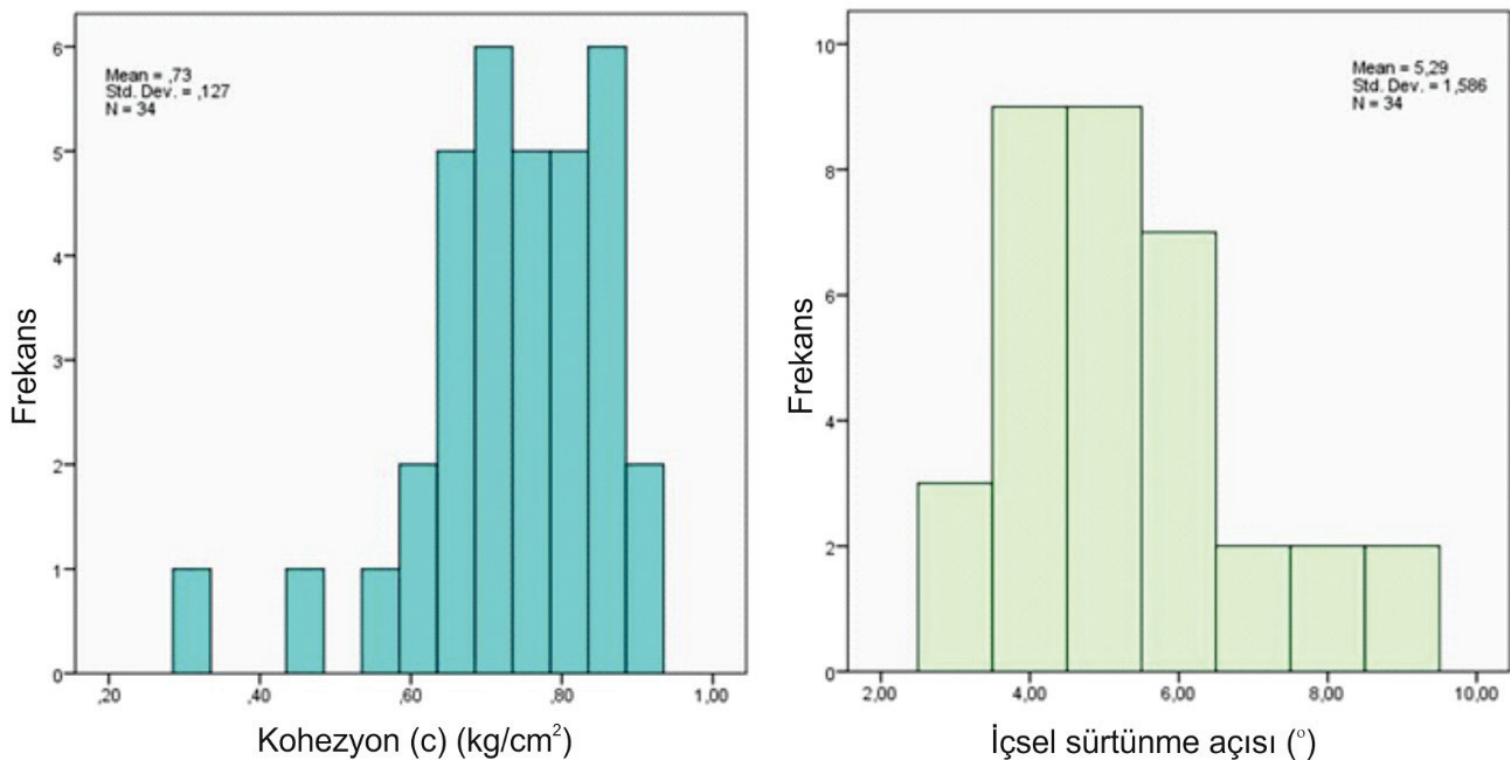

Şekil 13. Yüzüncü Yıl Üniversitesi kampüs alanındaki killi zeminlerin makaslama dayanım değerlerinin istatistiksel dağılımı. Figure 13. Statistical distribution of shear strength values of the clayey soils in the Yuzuncu Yil campus area.

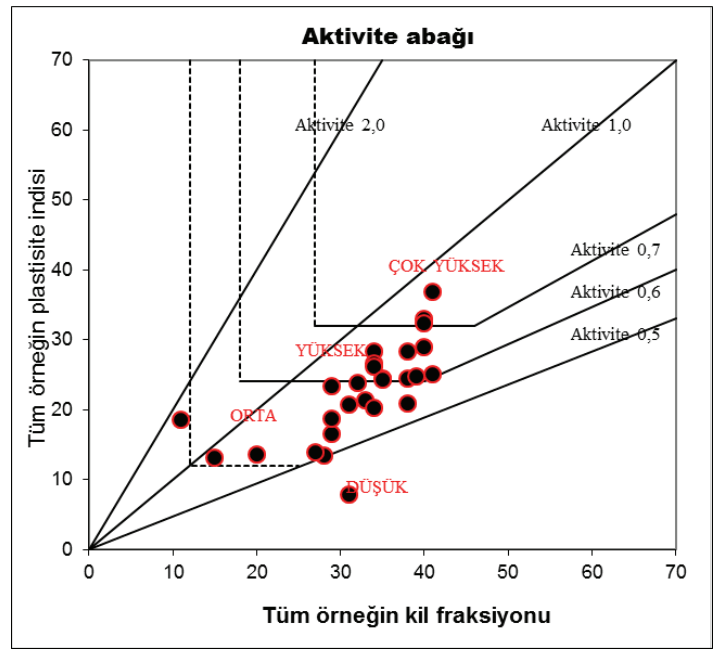

(a)

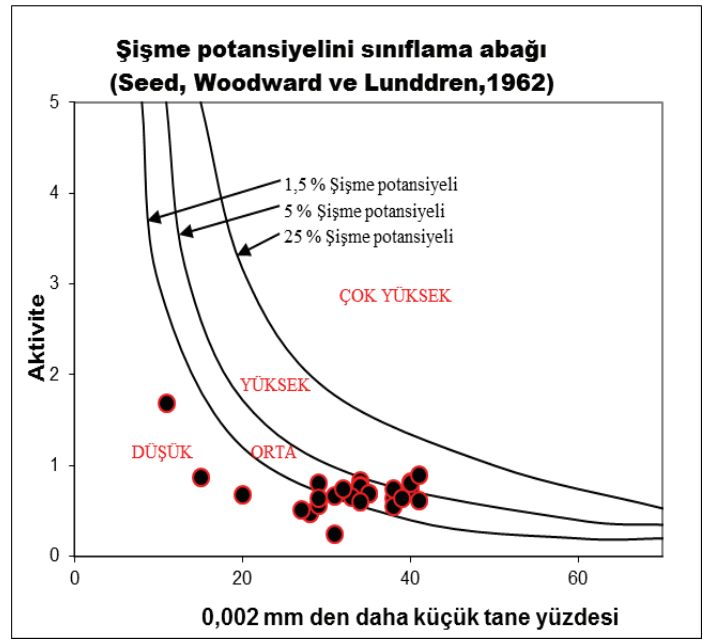

(b)

Şekil 14. YüzüncüYı1 Üniversitesi kampüs alanındaki killi zeminlerin (a) aktivitesinin ve (b) şişme potansiyelinin değerlendirilmesi. Figure 14. Evaluation of the clayey soils in the Yuzuncu Yil campus area with respect to a) activity and b) swelling potential. 
Şişme potansiyeli orta-yüksek olan killi zeminlerde yapilan hafif yapilarda (tek katlı binalar, altyapı iletim hatları, kaldırım vb.) zamana bağlı olarak şişme basınçlarının etkisi ile deformasyonlar gözlenebilir. Laboratuvarda incelenen örneklerin şişme basıç̧ları değerlendirildiğinde, kampüs alanındaki zeminlerin en düşük, ortalama ve en yüksek şişme basınçları sırasıyla $0.15 \mathrm{~kg} / \mathrm{cm}^{2}, 0.23 \mathrm{~kg} / \mathrm{cm}^{2}$ ve $0.29 \mathrm{~kg} / \mathrm{cm}^{2}$ olarak saptanmıştır. Laboratuvar deneyleri sonucunda belirlenen kampüs killi zeminlerine ait şişme basınc1 değerlerinin istatistiksel dağ 1 lımı Şekil 15 'te verilmiştir.

Kampüs alanında yapılan sondajlardan alınan örselenmemiş örnekler üzerinde gerçekleştirilen konsolidasyon deneyleri sonucunda, inceleme alanındaki killi seviyelerin önkonsolidasyon basınçları ve buna bağlı olarak aşırı konsolidasyon oranları belirlenmiştir
(Çizelge 1). Öte yandan SK12-UD1 örneğine ait önkonsolidasyon basincının Casagrande yöntemiyle hesaplandığ 1 konsolidasyon grafiği Şekil 16'da sunulmuştur. Kampüs alanındaki zeminlerin aşırı konsolidasyon oranı değerleri 1.14 ile 1.90 arasında değişmekte olup, bu değerler kampüs alanındaki killi zeminlerin aşırı konsolide olduğuna işaret etmektedir. Bilindiği üzere, aşırı konsolide killer oturma ve taşıma gücü açısından önemli bir sorun teșkil etmemektedir. $\mathrm{Bu}$ nedenle kampüs alanındaki killi zeminlerde oturma ve taşıma gücü probleminden çok, şişmeye dönük problemler beklenmektedir. Elde edilen bu sonuçlar genel değerlendirmeler olup, planlanacak yeni yapilarda temel zeminden alınacak örselenmemiş örnekler ile taşıma gücü, konsolidasyon ve şişme basınçlarına yönelik ayrıntılı değerlendirmelerin ayrıca yapılması gerekmektedir.

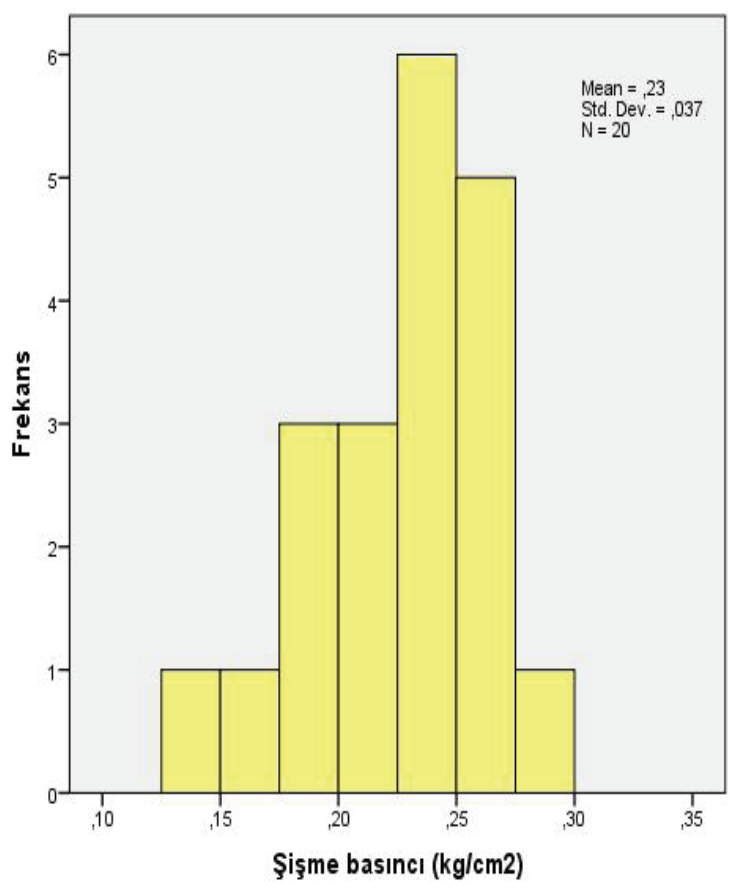

Şekil 15. Yüzüncü Y1l Üniversitesi kampüs alanındaki killi zeminlerin şişme basıncı değerlerinin istatistiksel dağılımı.

Figure 15. Statistical distribution of the swelling pressure of the clayey soils in the Yuzuncu Yil campus area. 
Çizelge 1. Yüzüncü Y1l Üniversitesi kampüs alanındaki killi zeminlerin aşırı konsolidasyon oranları.

Table 1. Overconsolidation ratio of the clayey soils in the Yuzuncu Yil Campus area.

\begin{tabular}{lcccc}
\hline Örnek No & Derinlik (m) & $\begin{array}{c}\text { Düşey efektif } \\
\text { gerilme }(\mathrm{kPa})\end{array}$ & $\begin{array}{c}\text { Önkonsolidasyon } \\
\text { basinc1 (kPa) }\end{array}$ & $\begin{array}{c}\text { Aş1r1 } \\
\text { konsolidasyon } \\
\text { oran1 }\end{array}$ \\
\hline ESK1-UD1 & $3.00-3.50$ & 62.7 & 74 & 1.18 \\
\hline ESK4-UD1 & $4.50-5.00$ & 95.0 & 108 & 1.14 \\
\hline ESK5-UD1 & $3.00-3.50$ & 62.1 & 83 & 1.34 \\
\hline ESK6-UD2 & $6.00-6.50$ & 118.8 & 137 & 1.15 \\
\hline ESK8-UD1 & $3.00-3.50$ & 63.7 & 80 & 1.26 \\
\hline SK12-UD1 (TOKİ lojmanlar) & $5.50-6.00$ & 99.8 & 190 & 1.90 \\
\hline
\end{tabular}

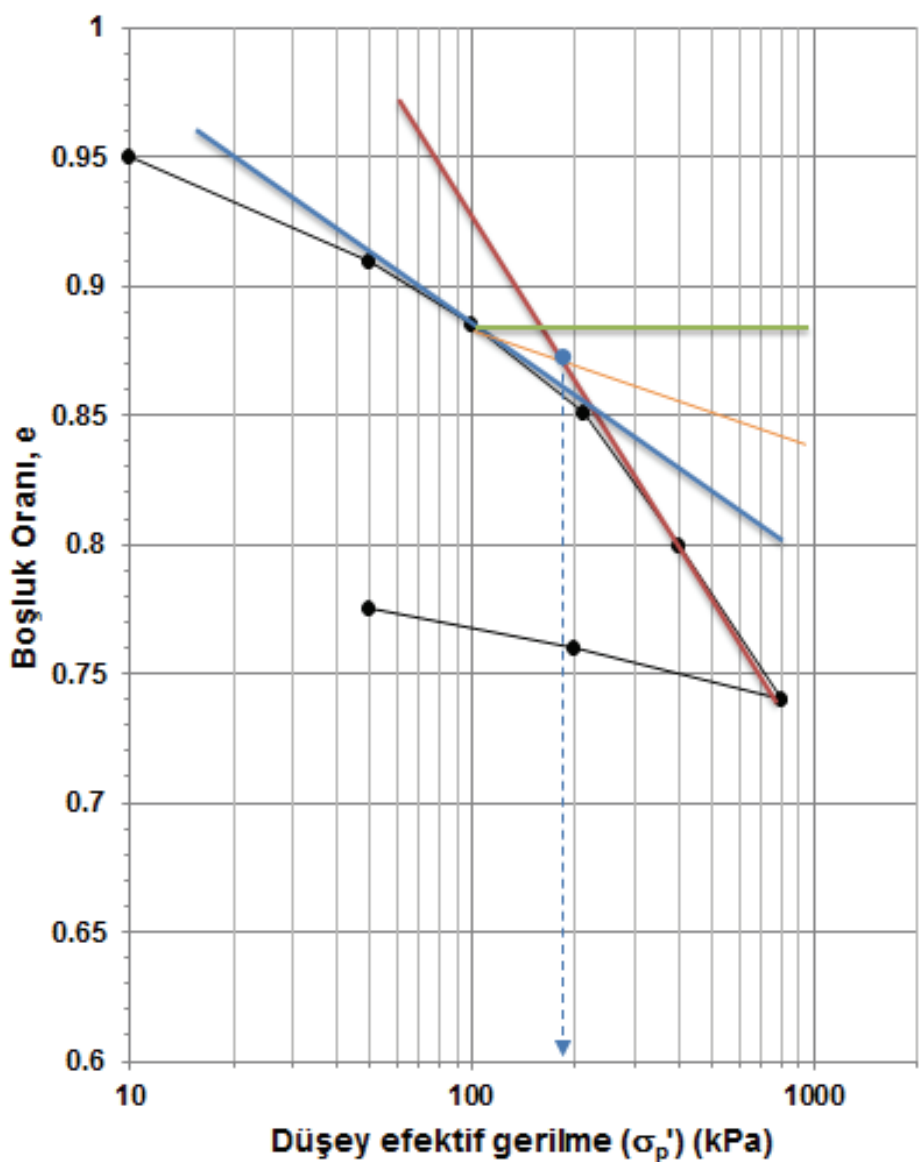

Şekil 16. SK12-UD1 nolu örneğe ait konsolidasyon grafiği ve önkonsolidasyon basınc1 hesab1.

Figure 16. Consolidation graph of SK12-UD1 specimen and determination of preconsolidation pressure. 
Akın, Akın, Akkaya, Özvan, Üner, Selçuk, Tapan

Kampüs alanında yapılan 45 adet sondajda, 520 adet SPT yapılmış olup, elde edilen SPT $\mathrm{N}_{30}$ değerlerinin istatistiksel dağılımı Şekil $17^{\prime}$ de gösterilmiştir.
Şekil 17'de tüm zeminler, ince taneli zeminler ve iri taneli zeminler için SPT $\mathrm{N}_{30}$ darbe sayıları ayrı ayrı incelenmiştir. Tüm zeminler için yapılan değerlendirmede kampüs
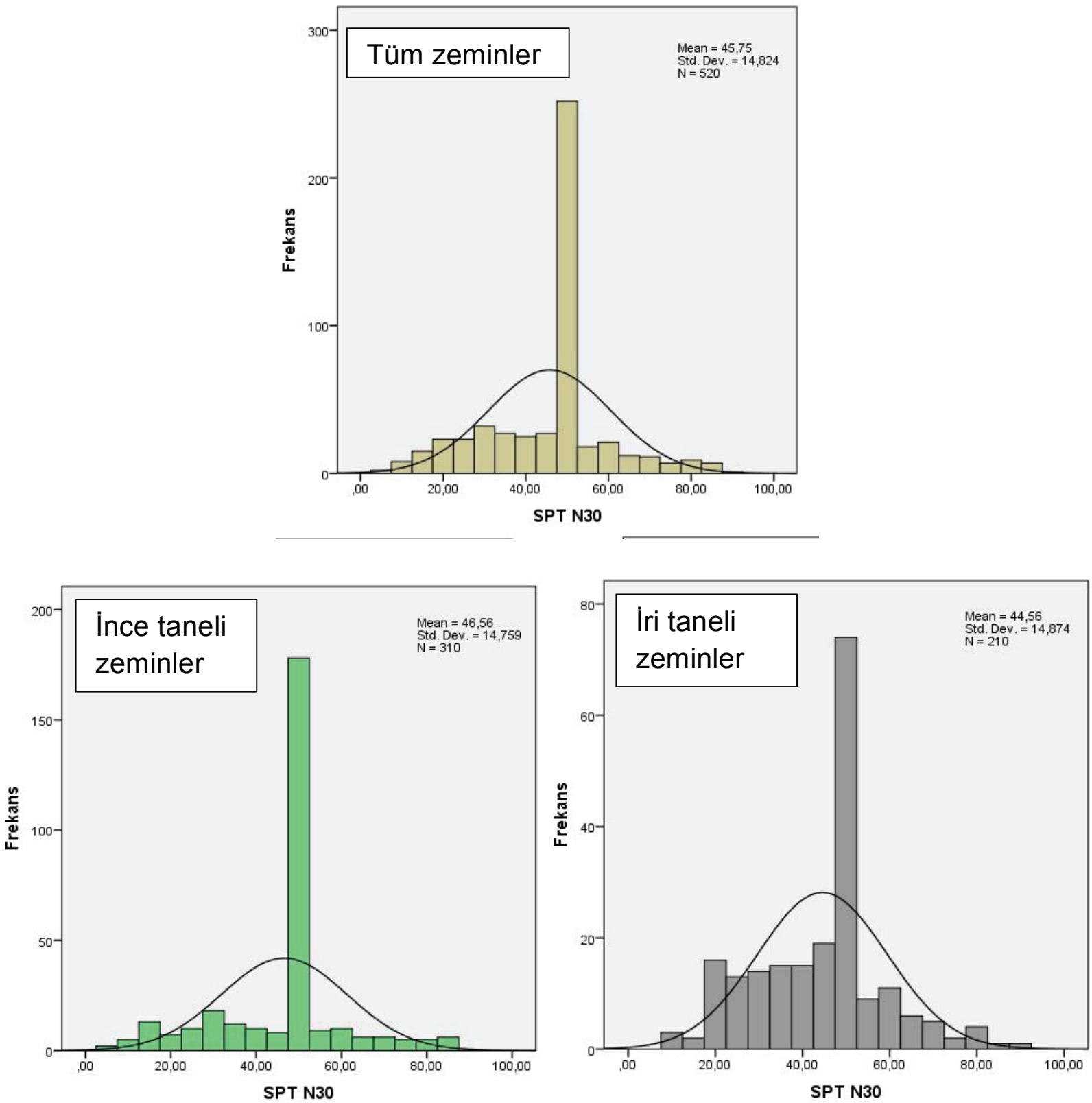

Şekil 17. Yüzüncü Y1l Üniversitesi kampüs alanındaki zeminlerin SPT $\mathrm{N}_{30}$ değerlerinin istatistiksel dağılımı.

Figure 17. Statistical distribution of SPT $N_{30}$ values of the soils in the Yuzuncu Yil campus area. 
alanındaki zeminlerde ortalama SPT $\mathrm{N}_{30}$ darbe sayısının 46 civarında olduğu görülmektedir. İnce taneli zeminlerde bu değer 47 , iri taneli zeminlerde ise 45 dolaylarındadır. Grafiklerde, dağılımın homojenliğini bozan ve diğer değerlere k1yasla belirgin oranda fazla bulunan değer 50 olarak bulunmuştur. SPT $\mathrm{N}_{30}$ değerlerinin istatistiksel dağılımı, inceleme alanındaki ince ve iri taneli zeminlerin oldukça katı ve sık1 olduğunu göstermektedir. Bu durum, jeoteknik açıdan olumlu kabul edilebilecek bir sonuçtur ve statik koşullarda taşıma gücü ve oturmalar açısından genel olarak problemsiz zeminleri işaret etmektedir.

\section{ANALIZLER VE DEĞERLENDİRME}

\section{Mikrotremör Analizleri}

Kampüs alanından elde edilen mikrotremor verilerine göre alanın genelinde periyot

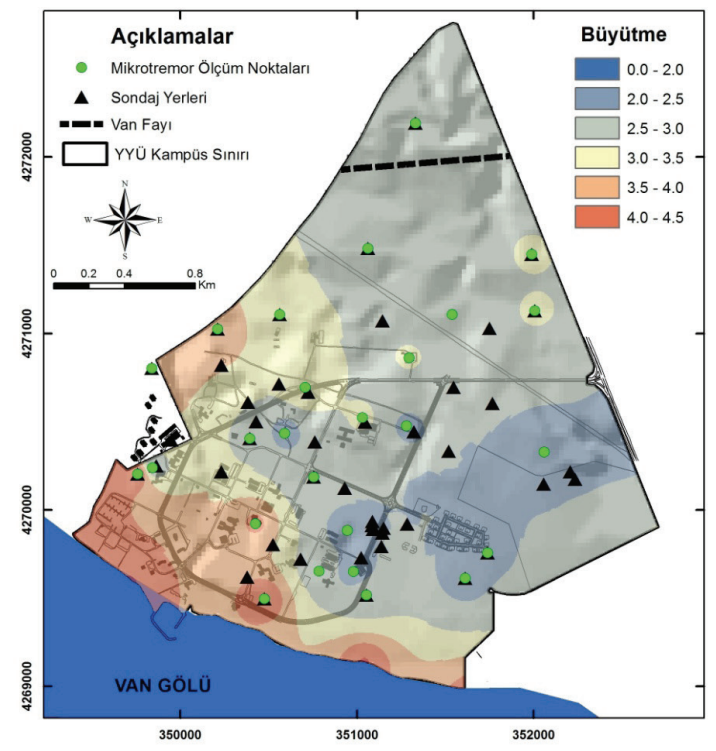

a) değerlerinin 0.5-1.5 sn arasında olması, çalışma alanının genelde kalın, yeryeryumuşak ve sert eski göl çökellerinden oluştuğunu göstermektedir. $\mathrm{Bu}$ bölgelerde zemin büyütme değerleri ise 2.0 - 4.5 kat arasında değişmektedir (Şekil 18). Özellikle kampüs alanının Van Gölü'ne yakın bölgelerine doğru büyütme değerlerinin arttı̆̆ 1 görülmektedir. $\mathrm{Bu}$ artış zeminin suya doygun ve gevşek olması ile ilişkili olup, bu zemin özelliklerinin, özellikle göl kıyısına yakın bölgelerde sondaj verilerindeki zemin özelliklerine de bağlı olarak, yer yer daha yumuşak-sıkı olduğu belirlenmiştir.

Kampüs alanının orta ve kuzey kesimlerinden elde edilen yüksek periyot değerleri, alüvyon kalınlığı ile ilişkiliyken, aynı bölgelerde elde edilen göreceli olarak düşük büyütme değerleri (2.0 - 2.5) bu kısımların daha s1k1 olduğunun göstergesidir. Aynı bölgede yapılan sondajlardan bu kismın sert kil ve yer yer s1k1 kum birimlerden oluştuğu belirlenmiştir.

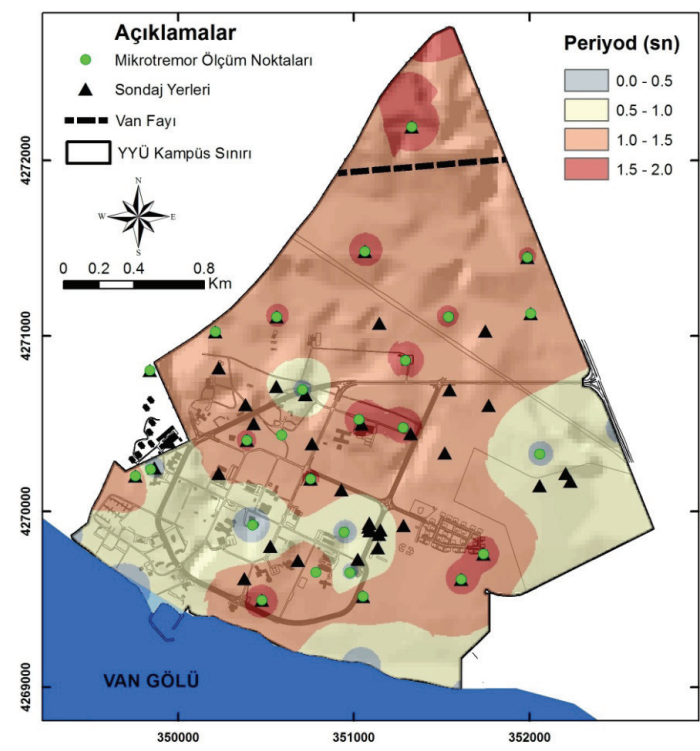

b)

Şekil 18. Çalışma alanında ölçülen mikrotremor kayıtlarından elde edilen büyütme (a) ve zemin hakim titreşim periyot haritası (b).

Figure 18. (a) Amplification and (b) dominant ground vibration period map obtained from measured microtremor periods in the study area. 
Akın, Akın, Akkaya, Özvan, Üner, Selçuk, Tapan

\section{Sıvılaşma Analizleri}

Önceki çalışmada ve mevcut çalışma kapsamında yapılan sondajlar dikkate alınarak, 45 adet sondaj kuyu verisinden sıvılaşma analizi yapılmıştır. İnceleme alanındaki zeminlerin sıvılaşma potansiyeli Iwasaki vd. (1982) tarafından önerilen Sıvılaşma Potansiyeli İndeksi (LPI) ve Sönmez ve Gökçeoğlu (2005)'na ait Sıvılaşma Şiddeti İndeksi (LSI) yöntemleriyle değerlendirilmiştir. Sıvılaşma analizlerinde derinlik ve örnekleme açısından standartlara uygun olan 45 adet sondaj kuyusu verisi dikkate alınmıştır. Sıvılaşmaya karşı güvenlik katsayılarının $\left(\mathrm{FS}_{\mathrm{L}}\right)$ belirlenmesinde, Standart Penetrasyon Deneyi(SPT) verilerinin kullanıldığı ve Devirsel Dayanım Oranı (CRR) ile Devirsel Gerilme Oranı (CSR) arasındaki ilişkinin esas alındı $\breve{g}_{1}$ Idriss ve Boulanger (2006) yönteminden yararlanılmıştır. Sıvılaşma analizlerinde maksimum deprem büyüklügü 7.2 ve maksimum yatay yer ivmesi $0.4 \mathrm{~g}$ olarak dikkate alınmıştır. Yüzüncü Y1l Üniversitesi kampüs alanına ait LPI ve LSI yöntemlerinden elde edilen sonuçlara göre hazırlanan sıvılaşma potansiyeli haritaları Şekil 19 ve 20'de sunulmuştur.

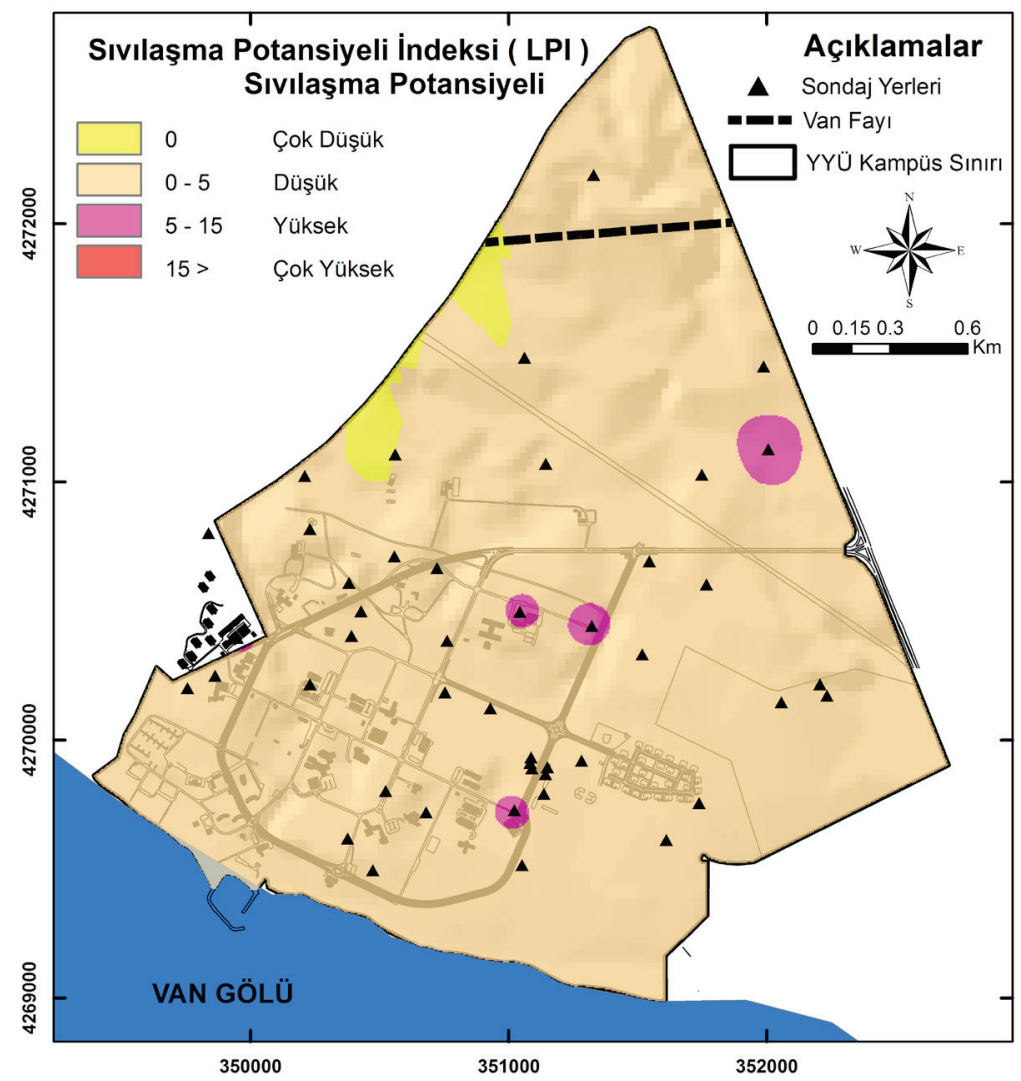

Şekil 19. Yüzüncü Y11 Üniversitesi kampüs alanı Sıvılaşma Potansiyeli İndeksi (LPI) haritası.

Figure 19. Liquefaction Potential Index (LPI) map of the Yuzuncu Yil campus area. 


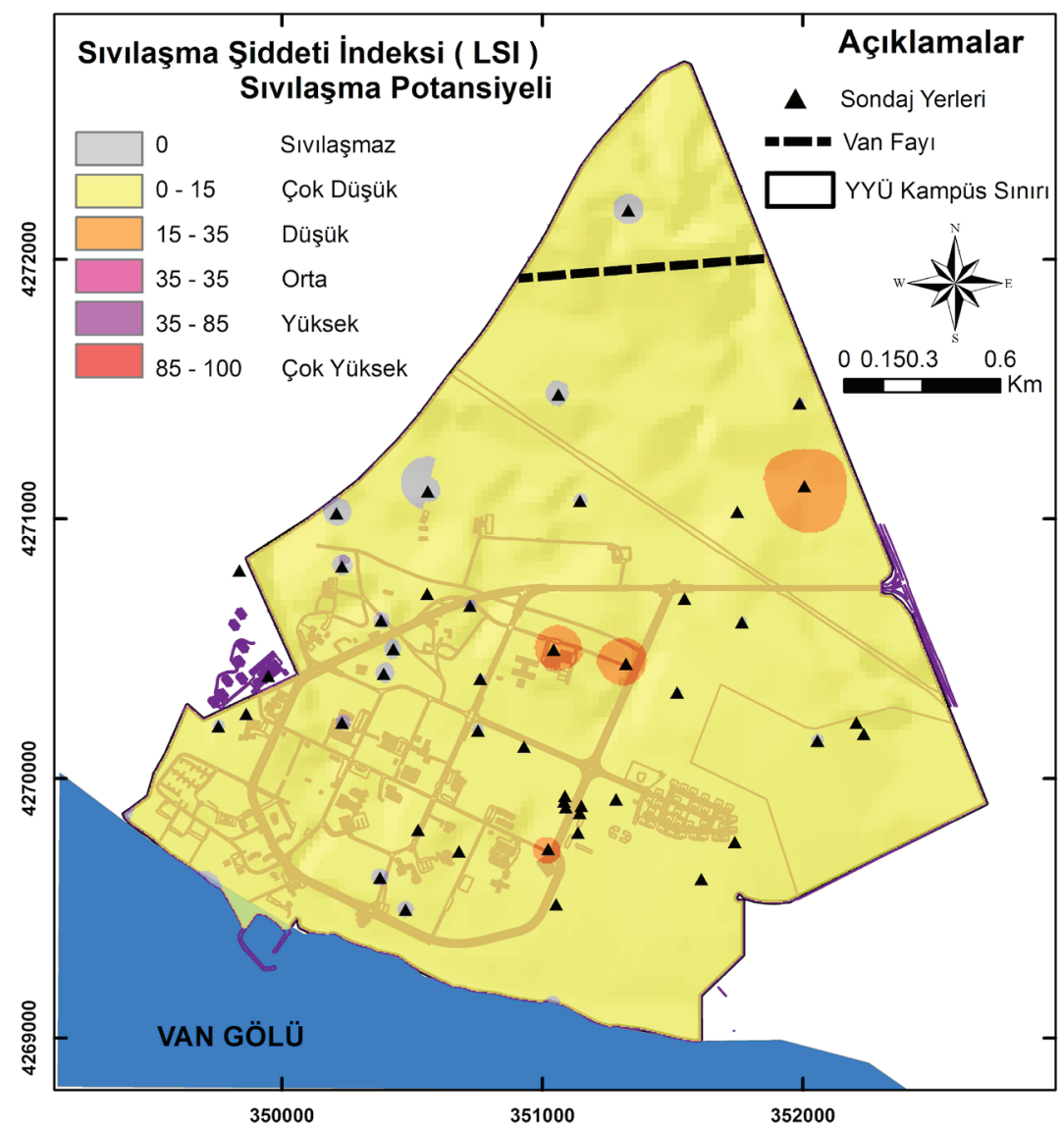

Şekil 20. Yüzüncü Y1l Üniversitesi kampüs alanı Sıvılaşma Şiddeti İndeksi (LSI) haritası.

Figure 20. Liquefaction Severity Index (LSI) map of the Yuzuncu Yil campus area.

LPI yönteminden elde edilen harita incelendiğinde çalışma alanındaki sıvılaşma potansiyelinin genel olarak "düşük - çok düşük" olduğu görülmektedir. Sadece yeraltısuyu seviyesinin yüzeye yakın olduğu ve gevşek kumlu zeminlerin hakim olduğu birkaç kuyuda "yüksek" sıvılaşma potansiyeli saptanmıştır. Öte yandan, LSI yöntemine göre hazırlanan harita incelendiğinde, çalışma alanındaki zeminlerin bir bölümünün sıvılaşmayacağı dikkati çekmektedir. Diğer kuyularda ise sıvılaşma potansiyeli LSI yöntemine göre "düşük - çok düşük” olarak tespit edilmiştir.

LPI ve LSI yönteminden elde edilen haritalar genel olarak değerlendirildiğinde kampüs alanındaki zeminlerin sıvılaşma potansiyellerinin çok düşük olduğu veya dinamik koşullar altında sıvılaşmayacağı ifade edilebilir. Sivılaşabilen zeminler oldukça lokal olarak bulunmaktadır. Sıvılaşma potansiyelinin düşük olmasının en önemli nedeni, inceleme alanında geniş bir yayılım gösteren eski göl çökellerinin oldukça 
sık1 (iri taneli seviyeler) veya katı (ince taneli seviyeler) bir özellik sergilemesidir. Bunun bir göstergesi olarak, SPT deneylerinde özellikle 5-6 metreden sonra çoğu lokasyonda eski göl çökelleri refü değeri vermektedir. Öte yandan, sıvılaşmaya duyarlı daha genç çökellerin kampüs alanındaki yayılımı da oldukça sınırlıdır. Bu tür gevşek zeminler çoğunlukla eski dere yatakları boyunca sığ bir derinlikte dağılım sergilemektedir.

\section{Çalışma Alanındaki Kesme Dalgası Hızları $\left(\mathrm{V}_{\mathrm{s} 30}\right)$ İçin Değerlendirmeler}

Dinamik etkiler altındaki zemin davranışları en iyi dinamik zemin parametreleri ile ifade edilmektedir. $\mathrm{Bu}$ nedenle çalışma alanındaki zeminlerin özellikle kesme dalga hızları $\left(\mathrm{V}_{\mathrm{s}}\right)$ farklı yöntemler dikkate alınarak değerlendirilmiştir.
$\mathrm{Bu}$ yöntemler arasında arazide yapılan Standart Penetrasyon Deneyi'ndeki son 30 cm'lik darbe sayısı toplamı ile kesme dalga hızının arasındaki ilişkiyi öne çıkaran yaklaşımlar dikkate alınmıştır. Farklı zemin tipleri için ampirik olarak SPT-N'ye karşılık $\mathrm{V}_{\mathrm{s}}$ ilişkileri çeşitli araştırmacılarca çalışılmıştır (Akın vd., 2011). Daha önceki ve yeni yapılmış olan sondaj çalışmaları da dikkate alınarak kampüs alanında 45 adet sondaj kuyusundaki SPT-N değerleri dikkate alınarak inceleme alanına ait $\mathrm{V}_{\mathrm{s}}$ dağılımı belirlenmiştir. Akın vd. (2011)'e göre önerilen eşitlik dikkate alınarak hem SPT ve hem de derinlik faktörlerinin yer aldığı $\mathrm{V}_{\mathrm{s}}$ hızları çalışma alanı için değerlendirilmiştir. $\mathrm{V}_{\mathrm{s}}$ hızlarından 30 metre derinlik için $\mathrm{V}_{\mathrm{s} 30}$ hızları belirlenerek haritalanmıştır (Şekil 21).

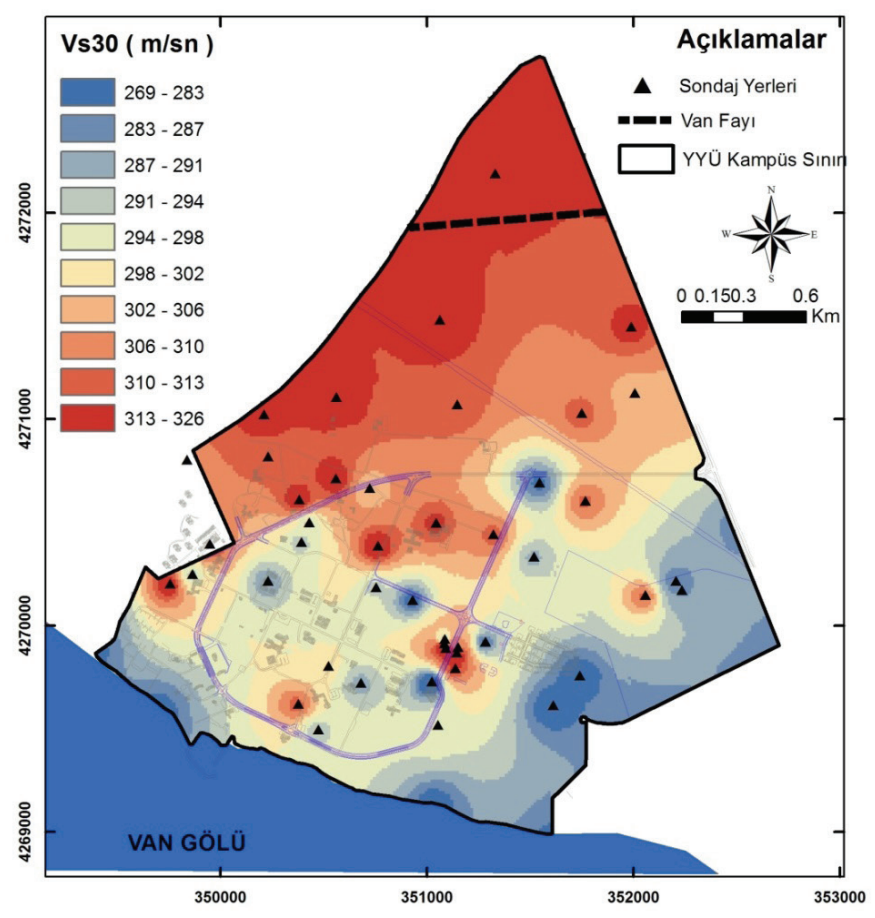

Şekil 21. Yüzüncü Y1l Üniversitesi kampüs alanı $\mathrm{Vs}_{30}$ dağ1lım haritas1

Figure 21. Vs $s_{30}$ distribution map of the Yuzuncu Yil campus area. 
$\mathrm{Vs}_{30}$ hiz verisi kullanılarak NEHRP (2000)'e göre yapılan zemin sinıflamasında, çalışma alanında D türü zemin (katı özellikte zemin) bulunmaktadır.

\section{Yerleşime Uygunluğun Değerlendirilmesi}

Yapılan analizlere bağlı olarak jeoloji, yükseklik, sıvılaşma potansiyeli, zemin sınıfı, zemin büyütme ve frekans dağılımlarına yönelik hazırlanan haritalar, Coğrafi Bilgi Sistemi (CBS) ortamında birlikte değerlendirilerek, çalışma alanı için yerleşime uygunluk değerlendirilmesi yapılmıştır (Şekil 22). Bu haritaya göre, faya yakın olan alanlar yerleşime uygun olmayan alanlar olarak belirlenmiştir. Van Gölü kıyısından kampüs alanında kuzeye doğru gidildikçe yerleşime uygunluk derecesi giderek yükselmektedir. Buna göre kampüs alanı yapılan analizler sonucunda düşük, orta ve yüksek derecede uygun alanlar olarak sınıflanmıştır (Şekil 22). Kampüs alanının geneli orta derecede yerleşime uygun alan olarak sınıflandırılmıştır. Göle yaklaştıkça yerleşime uygunluk oranı azalmaktadır. 23 Ekim 2011 depreminin yüzey kırığı dikkate alındığında, bu fayın güneyinden ve kuzeyinden olmak üzere güvenli tarafta kalmak amaciyla 100'er metrelik tampon bölge dikkate alınmış ve bu bölge yerleşime uygun olmayan bölge olarak tanımlanmıştır. Sadece fay olmasından ötürü bu bölge uygun olmayan alan olarak sınıflanmıştır.

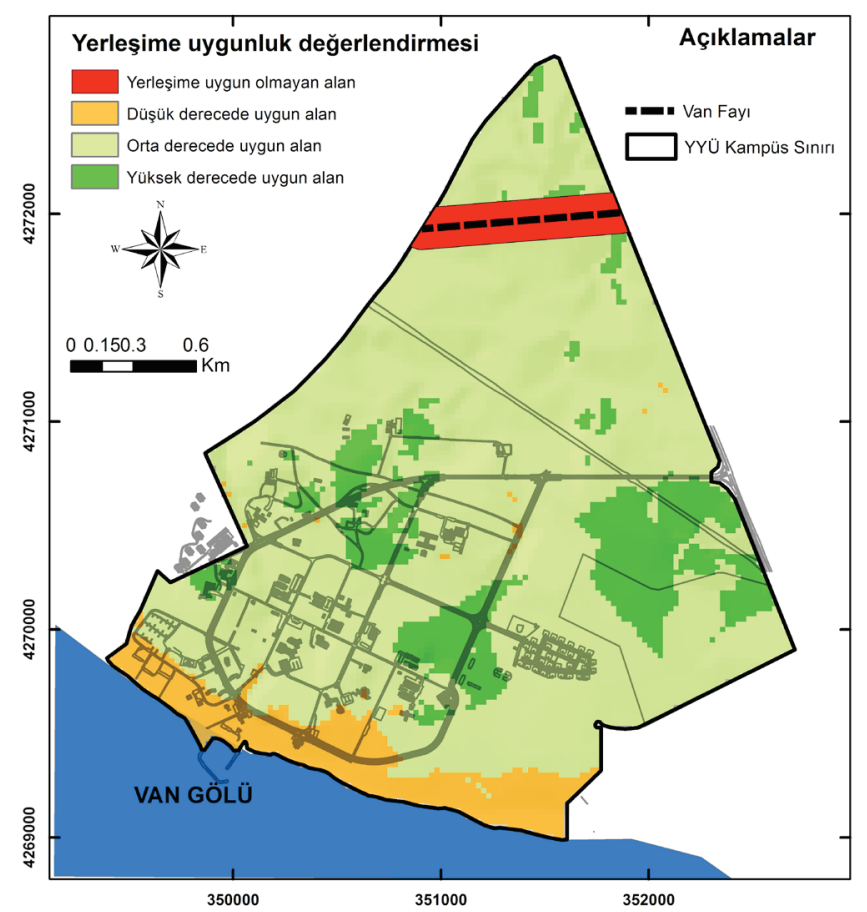

Şekil 22. Yüzüncü Y11 Üniversitesi kampüs alanı yerleşime uygunluk değerlendirme haritası.

Figure 22. Evaluation of the settlement suitability of the Yuzuncu Yil campus area. 
İnceleme alanında yerleşime uygunluk değerlendirilirken, AFAD tarafindan önerilen yerleşime uygunluk mevzuatı kapsamında, kampüs şartları da gözönünde bulundurularak yerleşime uygun olan alanlar dereceli bir geçiş sisteminde değerlendirilmiştir. Kampüs alanı içerisinde yüksek ve orta derecede uygun olan alanlar, yapılaşmanın oldukça fazla olduğu ve deprem sonrasinda mevcut binalarda yapilan güçlendirmeler ile yerleşimin yapıldığı alanları temsil etmektedir. Özellikle orta-yüksek derecede yerleşime uygun olan alanlarda, üniversite personeli için, yeni deprem yönetmeliğine uygun olarak TOKİ tarafindan 2012'de 496 adet konut inşa edilmiştir. Düşük derecede yerleşime uygun olan alanlarda peyzaj çalıması ile kıyı şeridine gidilebileceği için bu alanda yapılaşmanın çok da güvenli olmayacağı belirlenmiştir. Yine yeni yapılan ve yapılacak yapılarda yeni deprem yönetmeliğine uygunluk aranmasından ve gerekli zemin ve yapısal iyileştirmelerin yapılacağından dolayı, bu dereceli yerleşime uygunluğun dikkate alınması önerilmektedir.

\section{SONUÇLAR}

YYÜ kampüs alanı için hazırlanan yerleşime uygunluk haritas1, gelecekteki yapılaşmalara yol gösterici nitelikte olup, kampüs genelindeki zeminlerin heterojen bir yapı göstermesi ve kısa mesafelerde değişebilmesi nedeniyle, yapılacak tüm yeni yapılarda ayrıntılı (sondaj, jeofizik vb.) jeoteknik etüt çalışmaları yaptırılmalıdır. Öte yandan, YYÜ kampüs alanının kuzey sınırına yakın bir bölümünden geçen Van fayına paralel/paralele yakın şekilde olabilecek olası faylara yönelik detaylı fay araştırmaları gerçekleştirilmelidir. Ortaya konulan yerleşime uygunluk haritasında Van Gölü kıyısına yaklaşıldıkça yerleşime uygunluk oranı düşmekte olup, kampüs alanında kuzeye doğru gidildikçe yerleşime uygunluk oranı artmaktadır. Ancak Van fayına yakın olan bölgeye yaklaşıldığında fay kırı̆ğ izi belli bir tampon bölge kabul edilerek fay ve yakın çevresinde yerleşimden kaçınılmalıdır.

\section{KATKI BELIRTME}

$\mathrm{Bu}$ çalışma 2011-YNL-MİM.01 numaralı proje ile YÜZÜNCÜ YIL ÜNIVERSITESI Bilimsel Araştırmalar Proje Başkanlığı (BAP) tarafından desteklenmiştir. Finansal desteği için YYÜ BAP'a ve değerli görüş ve bilgileriyle katkıda bulunan hakemlere teşekkür ederiz.

\section{KAYNAKLAR}

Acarlar, M., Bilgin, E., Elibol, E., Erkal., T., Gedik, İ., 1991. Van gölü doğu ve kuzeyinin jeolojisi. MTA Genel Müdürlüğü, Arşiv No: 1061, Ankara.

Akın, M., 2009. Seismic microzonation of Erbaa (Tokat-Turkey) located along eastern segment of the North Anatolian Fault Zone. Graduate School of Natural and Applied Sciences of Middle East Technical University, Ankara, Ph.D. Thesis, 416 $\mathrm{p}$ (unpublished)

Akın K. M., Kramer S. L., Topal, T., 2011. Empirical correlations of shear wave velocity $\left(\mathrm{V}_{\mathrm{s}}\right)$ and penetration resistance (SPT-N) for different soils in an earthquake-prone area (Erbaa-Turkey). Engineering Geology, 119 (1-2), 1-17.

Akın, M., Ozvan, A., Akın, K. M., Topal, T., 2013. Evaluation of liquefaction in Karasu River floodplain after the October 23, 2011, Van (Turkey) earthquake. Natural Hazards, Vol. 69, 1551-1575.

Aksoy, E., 1988. Van ili doğu-kuzeydoğu yöresinin stratigrafi ve tektoniği. Firat Üniversitesi Fen Bilimleri Enstitüsü, Elazığ, Doktora Tezi, $171 \mathrm{~s}$ (yayımlanmamış). 
Ansal, A., 1999. Strong ground motions and site amplification. Theme Lecture, $2^{\text {nd }}$ International Conference on Earthquake Geotechnical Engineering, Balkema, Rotterdam, Ed. P. S. Pinto, Vol. 3, 879-894.

Ansal, A., Iyisan, R., Yıldırım, H., 2001. The cyclic behaviour of soils and effects of geotechnical factors in microzonation. Soil Dynamics and Earthquake Engineering, 21, 445-452.

Ansal, A., Laue, J., Buchheister, J., Erdik, M., Springman, S., Studer, J., Koksal, D., 2004. Characterization and site amplification for a seismic microzonation study in Turkey. $11^{\text {th }}$ International Conference on Soil Dynamics and Earthquake Engineering, $3^{\text {rd }}$ International Conference on Earthquake Geotechnical Engineering, Berkeley, California, USA, 8 p.

Bell, F.G., Cripps, J.C., Culshaw, M.G., O’Hara, M., 1987. Aspects of geology in planning. In: Culshaw, M. G., Bell, F. G., Cripps, J. C., O’Hara, M. (Eds.), Planning and Engineering Geology, Geological Society Engineering Geology Special Publication, 4, 1-38.

Bozkurt, E., 2001. Neotectonics of Turkey-a synthesis. Geodynamica Acta, 14, 3-30.

CEDIM, 2011. Comparing the current impact of the Van Earthquake to past earthquakes in Eastern Turkey. Center for Disaster Management and Risk Reduction Technology (CEDIM), Forensic Earthquake Analysis Group, Report 4, 28 p.

Dai, F. C., Liu, Y., Wang, S., 1994. Urban geology: a case study of Tongchuan City, Shaanxi Province, China. Engineering Geology, 38, 165-175.

Dai, F. C., Lee, C. F., Zhang, X. H., 2001. GIS-based geo-environmental evaluation for urban land-use planning: a case study. Engineering Geology, 61, 257-271.

Emre, Ö., Duman, T. Y., Özalp, S., Elmac1, H., 2011. 23 Ekim 2011 Van depremi saha gözlemleri ve kaynak faya ilişkin ön değerlendirmeler. MTA Genel Müdürlüğü Raporu, Ankara, 22 s.

GDDA, 1996. Earthquake zoning map of Turkey. General Directorate of Disaster Affairs, Ministry of Reconstruction and Resettlement of Turkey.

GDDA, 2000. Laws and regulations: regulations for the construction of buildings in hazard areas. Ankara, 244-332.

Hake, S. S., 1987. A review of engineering geological and geotechnical aspects of town and country planning with particular reference to minerals and the extractive processes. In: Culshaw, $M$. G., Bell, F. G., Cripps, J. C., O’Hara, M. (Eds.), Planning and Engineering Geology, Geological Society Engineering Geology Special Publication, 4, 69-74.

Idriss, I. M., Boulanger, R. W., 2006. Semi-empirical procedures for evaluating liquefaction potential during earthquakes. Soil Dynamics and Earthquake Engineering, 26, 115-130.

Iwasaki, T., Tokida, K., Tatsuoka, F., Watanabe, S., Yasuda, S., Sato, H., 1982. Microzonation for soil liquefaction potential using simplified methods. Proceedings of the $3^{\text {rd }}$ International Conference on microzonation, Seattle, 3, 1310-1330.

Kanai, K., Tanaka, T., 1954. On microtremors I. Bulletin of the Earthquake Research Institution, 32, 199-209.

Kanai, K., Tanaka, T., 1961. On Microtremors VIII. Bulletin of Earthquake Research Institution, University of Tokyo, 39, 97-114.

KOERİ, 2011. Probabilistic Assessment of the Sismic Hazard for the Lake Van Basin, Ocotober, 23, 2011 (Son erişim: 23 Aralık 2011).

Koçyiğit, A., Yilmaz, A., Adamia, S., Kulashvili, S., 2001. Neotectonics of East Anatolian Plateau (Turkey) and Lesser Caucasus: Implication for transition from thrusting to strike-slip faulting. Geodinamica Acta, 14, 177-195. 
Koçyiğit, A., 2013. New field and seismic data about the intraplate strike-slip deformation in Van region, East Anatolian Plateau, Turkey. Journal of Asian Earth Sciences, 62, 586-605.

Legget, R. F., 1987. The value of geology in planning. In: Culshaw, M. G., Bell, F. G., Cripps, J. C., O'Hara, M. (Eds.), Planning and engineering geology. Geological Society Engineering Geology Special Publication. 4, 53-58.

Nakamura, Y., 1989. A method for dynamic characteristics estimation of subsurface using microtremor on the gorund surface. Quarterly Report of Railway Technical Research Institute, 30 (1), 25-33.

NEHRP, 2000. Recommended Provisions for Seismic Regulations for New Buildings and other Structures, Part 1: Provisions, FEMA 368. Building seismic safety council of the National Institute of Building Sciences, USA, $392 \mathrm{p}$.

Örçen, S., Tolluoğlu, S., Köse, O., Yakupoğlu, T., Çiftçi, Y., Işık, M. A., Selçuk, L., Üner, S., Özkaymak, Ç., Akkaya, İ., Özvan, A., Sağlam, A., Baykal, M., Özdemir, Y., Üner, T., Karaoğlu, Ö., Yeşilova, Ç., Oyan, V., 2004. Van Şehri kentleşme alanında yüzeyleyen Pliyo-Kuvaterner çökellerindeki Sedimantolojik özelliklerin ve aktif tektonizmanın depremselliğe yönelik incelenmesi. TÜBITAK, YDABAG-101Y100 (VAP-10).

Özkaymak, Ç., 2003. Van şehri ve yakın çevresinin aktif tektonik özellikleri. Yüzüncü Yıl Üniversitesi Fen Bilimleri Enstitüsü, Van, Yüksek Lisans Tezi, $76 \mathrm{~s}$ (yayımlanmamış).

Özkaymak, Ç., Sözbilir, H., Bozkurt, E., Dirik, K., Topal, T., Alan, H., Çağlan, D., 2012. 23 Ekim 2011 Tabanl1-Van depreminin sismik jeomorfolojisi ve Doğu Anadolu'daki aktif tektonik yapıyla olan ilişkisi. Jeoloji Mühendisliği Dergisi, 35 (2), 175-199.
Özvan, A., Akkaya, İ., Yılmazer, İ., 2005. Van yerleşkesindeki killerin plastisite özellikleri. 12. Ulusal Kil Sempozyumu, Van, 485-492.

Rau, J. L., 1994. Urban and environmental issues in East and Southeast Asian coastal lowlands. Engineering Geology, 37, 25-29.

Seed, H. B., Woodward R. J., Lundgren, R., 1962. Prediction of swelling potential for compacted clays. Journal of the Soil Mechanics and Foundation Division, ASCE, 88, 53-87.

Selçuk, L., 2003. Yüzüncü Yıl Üniversitesi Zeve Kampüsü yerleşim alanının mühendislik jeolojisi. Yüzüncü Y1l Üniversitesi Fen Bilimleri Enstitüsü Jeoloji Mühendisliği Anabilim Dalı, Van, Yüksek Lisans Tezi, $150 \mathrm{~s}$ (yayımlanmamış).

Selçuk, L., Aydın, H., 2012. Kuvaterner yaşlı alüvyal zeminlerin kuvvetli yer hareketine etkisi: 2011 Van Depremleri. Jeoloji Mühendisliği Dergisi, 36 (2), 75-97.

Sönmez, H., Gökçeoğlu, C., 2005. A liquefaction severity index suggested for engineering practice. Environmental Geology, 48, 81-91.

Şaroğlu, F., Yılmaz, Y., 1986. Doğu Anadolu'da neotektonik dönemdeki jeolojik evrim ve havza modelleri. MTA Genel Müdürlüğü, Jeoloji Etütleri Dairesi, Ankara.

Topal, T., Doyuran, V., Karahanoglu, N., Toprak, V., Suzen, M. L., Yeşilnacar, E., 2003. Microzonation for earthquake hazards: Yenişehir settlement, Bursa, Turkey. Engineering Geology, 70, 93-108.

Van Rooy, J. L., Stiff, J. S., 2001. Guidelines for urban engineering geological investigations in South Africa. Bulletin of Engineering and Geological Environment, 59, 285-295.

Wathelet, M., Jongmans, D., Ohrnberger, M., Bonnefoy-Claudet, S., 2008. Array performances for ambient vibrations on a shallow structure and consequences over $\mathrm{V}_{\mathrm{s}}$ inversion. Journal of Seismology, 12, 1-19. 